\title{
Trends and Patterns of Growth, Development, Achievements of China and India: A Comparative Analysis
}

\author{
Biswa Nath Bhattacharyay \\ Madhurima Bhattacharyay
}

\author{
CESIFO WORKING PAPER NO. 5788 \\ CATEgory 6: FisCAL Policy, MaCroeconomics AND GROWTH \\ MARCH 2016
}

An electronic version of the paper may be downloaded

- from the SSRN website:

- from the RePEc website:

www.SSRN.com

www.RePEc.org

- from the CESifo website:

www.CESifo-group.org/wp 


\title{
Trends and Patterns of Growth, Development, Achievements of China and India: A Comparative Analysis
}

\begin{abstract}
Even before the onset of the 2008 global financial crisis and ongoing European debt crisis, much attention has been given to the re-emergence of the Asian giants, the People's Republic of China (PRC) and India. Both countries have attained unprecedented growth and economic development-PRC and India became the second and fourth largest economies of the world, respectively. Moreover, these countries remarkably improved their per capita income as PRC increased its per capita GDP by 13-fold from US\$341 in 1990 to US\$4,421 in 2010 whereas India posted a four times growth from US\$384 in 1990 to US\$1,342 in 2010. This has resulted in a remarkable poverty reduction in the last two to three decades in the two economies. PRC and India share several common characteristics, prospects and challenges. However, their approaches to growth and development as well as growth models have been different. The major objective of this paper is to compare the policies, institutions, strategies, reforms and market conditions that contributed to the rapid growth and development of the PRC and India which can provide lessons to the developing world, particularly emerging economies, that are also struggling to improve their economic development and quality of life amidst economic growth. This paper attempts to examine the differences between PRC and India in terms of trends and patterns of growth and development, economic models, sources and drivers of growth; achievements, policies and institutions since last three decades.
\end{abstract}

JEL-Codes: O100, O110, O120, O200, O210, O240, O400, O430, O570.

Keywords: growth and development, People Republic of China, India, comparative analysis, economic reforms, models, policies and institutions, emerging economies.

Biswa Nath Bhattacharyay University of South Pacific, Fiji \& Asian Development Bank, Manila \& ADB Institute, Tokyo dr_biswa@yahoo.com
Madhurima Bhattacharyay

Desautels Management School

McGill University Montreal

Montreal / Quebec / Canada 


\section{Introduction}

Even before the onset of the 2008 global financial crisis, much attention has been given to the re-emergence of Asian giants, the People's Republic of China (PRC) and India. Both countries have attained unprecedented growth and economic development. This has resulted in remarkable poverty reduction in the last two to three decades in the two economies. PRC and India share several common characteristics, prospects and challenges. However, their approaches to growth and development as well as growth models have been different. Hence, it will be of interest to examine the differences between PRC and India in growth and development patterns and trends, economic models, sources and drivers of growth; achievements, policies and institutions. The developing countries, particularly emerging economies around the world can learn from their experience.

According to Maddison (2001), both the PRC and India dominated the global economy until the 1800 s, accounting for the highest shares in world GDP during the period. In recent decades, both countries are reemerging as the major global economic powers as India and the PRC have achieved high economic growth (Table 1 and Figure 1). Particularly, Table 1 shows that in the previous decades, the growth rates of both countries have caught up, if not exceeded, that of USA and Japan. In 2010, India and PRC posted real GDP growth rates of 9.6 percent and 10.4 percent, respectively, which was also the year when PRC has overtaken Japan in terms of share in GDP, making PRC the second largest economy in the world, next to the United States. Meanwhile, India is expected to become the third largest economy in 2012 in terms of GDP (PPP) in the world (Price Waterhouse Coopers 2010) due to its consistently high growth rates, in contrast with the low economic growth rates in major economies.

Figure 1. GDP, 1980-2010 (Current US \$)

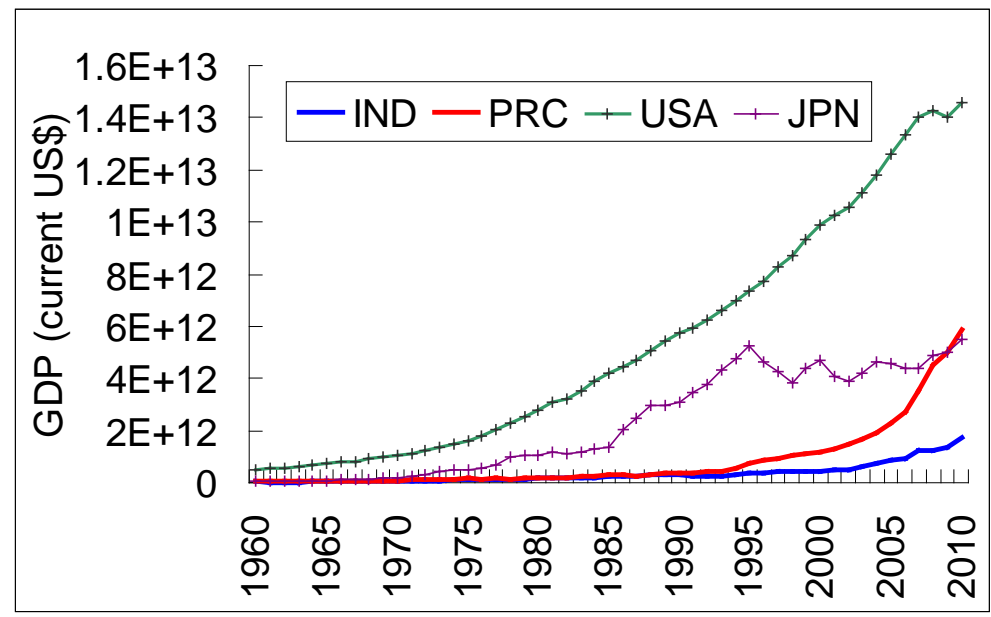

Source: World Development Indicators (2011)

The PRC and India are fast becoming key global economic players as their shares in the global economy, trade, finance and population continue to rise. As such, they are posed to become the global centers of production and will be future drivers of world consumption as their economies continue to develop. However, while both countries are expanding rapidly, both countries have different drivers of growth, taking different approaches in stimulating economic growth, strengthening their institutions and improving the quality of lives of their people.

In view thereof, this paper aims to investigate the different development and economic models adopted by PRC and India, the sources of growth of these two economies, and the policies and institutions that these countries have been implementing to facilitate the steering of their economies into the center stage of global economic affairs.

The major objective of this paper is to compare the policies, institutions, strategies, reforms and market conditions that led to the rapid growth and development of the PRC and India in order to provide lessons to the developing world, particularly emerging economies, which are also struggling to improve their economic development and quality of life amidst economic growth. 
This paper attempts to examine the differences between PRC and India in terms of trends and patterns of growth and development, economic models, sources and drivers of growth; achievements, economic reforms, strategies, policies and institutions since last three decades.

The paper is structured in the following way. The next section discusses the achievement or performances and drivers of economic growth (role of agriculture, manufacturing and service sectors) and development in the areas of savings, capital and investment; labor migration; education, role of technology and diaspora; . The third section elaborates the role and performance of trade and foreign direct investment. The fourth section examines the growth and development models of both countries including policy reforms and institution building, role of state and markets and trends in the development of entrepreneurs. The last section concludes by presenting appropriate policies to address the challenges ahead to further improve the development and growth prospects of the two economies.

\section{Economic Growth and Development: Achievements and Drivers}

PRC and India are often lauded for their robust economic reforms that were succeeded by remarkable economic growth. Studies on productivity provide a closer look at the factors that have driven these fast growth rates. Meanwhile, investment liberalization has attracted foreign capital into these countries. The internal migration from rural to modern sectors supplied the increased labor demand in the growing manufacturing sector in the PRC and service sector in India, while education has provided these migrants with skills necessary to be absorbed in the growing economy. Other factors such as technology and diaspora also played a role in growth and development of both countries. Thus, the major drivers of growth in both the PRC and India can be identified as productivity, savings, capital, investment, demographic dividend and labor migration, education and human capital development, technology, and the role of diaspora.

This section analyzes the trends and patterns in economic and population growth; productivity as well as drivers and sources of growth and development achievements.

\subsection{Trends and Patterns in Economic and Population Growth}

Since 1970, PRC and India have witnessed strong growth rates, with a few occasions of slow growth. PRC has exhibited continued rapid growth since 1995 whereas India has observed the same phenomenon since 2005 (Table 1).

Table 1. Comparative Real GDP Growth Rate (annual \%), 1965-2011

\begin{tabular}{|l|c|r|r|r|r|r|r|r|r|r|}
\hline Country & $\mathbf{1 9 6 5}$ & $\mathbf{1 9 7 0}$ & $\mathbf{1 9 8 0}$ & $\mathbf{1 9 8 5}$ & $\mathbf{1 9 9 0}$ & $\mathbf{1 9 9 5}$ & $\mathbf{2 0 0 0}$ & $\mathbf{2 0 0 5}$ & $\mathbf{2 0 1 0}$ & $\mathbf{2 0 1 1}$ \\
\hline India & -2.6 & 5.2 & 6.7 & 5.3 & 5.5 & 7.6 & 4.0 & 9.3 & 9.6 & 6.9 \\
\hline PRC & 16.4 & 19.4 & 7.8 & 13.5 & 3.8 & 10.9 & 8.4 & 11.3 & 10.4 & 9.3 \\
\hline USA & 6.4 & 0.2 & -0.3 & 4.1 & 1.9 & 2.5 & 4.2 & 3.1 & 3.0 & 1.7 \\
\hline Japan & 5.8 & -1.0 & 2.8 & 6.3 & 5.6 & 1.9 & 2.3 & 1.3 & 4.4 & -0.7 \\
\hline
\end{tabular}

Source: World Development Indicators (2012)

Comparing the historical real GDP growth rates of PRC and India, Table 2 shows that the average economic growth rate of PRC was higher than India in both pre-reform and post-reform periods. However, in terms of per capita income, India used to have higher GDP per capita compared to PRC prior to the implementation of reforms. In post-reform, the per capita GDP of PRC is almost twice that of India due to much faster economic growth of PRC. The gap between the average growth rates of PRC and India was more significant during the post-reform period. As the major global economies slowdown in light of the 2008 global financial crisis and recent European debt crisis, these two Asian giants are still posed to become two of the leading drivers of global growth. 
Table 2. Average Economic Growth rates of PRC and India: Pre and Post Reform Period

\begin{tabular}{|l|c|c|c|c|}
\hline & \multicolumn{2}{|c|}{ Growth Rate (\%) } & \multicolumn{2}{c|}{ GDP per capita (US\$) } \\
\hline & PRC & India & PRC & India \\
\hline Pre-reform & $(1960-1977)$ & $(1960-1990)$ & $(1960-1977)$ & $(1960-1990)$ \\
& 4.8 & 4.2 & 115.24 & 241.78 \\
\hline Post-reform & $(1978 \sim 2010)$ & $(1991 \sim 2010)$ & $(1978 \sim 2010)$ & $(1991 \sim 2010)$ \\
& 10.0 & 6.5 & 980.68 & 604.80 \\
\hline
\end{tabular}

Source: World Development Indicators (2012)

Population and demographic shifts are important factors influencing economic growth. The sheer size of the population of both India and PRC has global implications. In 2010, these countries already comprised almost $2 / 5$ of world population (Table 3 ). While in the past, PRC had utilized its demographic dividend for its rapid industrial expansion, it is expected to face aging population in the next decade due to its "one child policy" (Feng 2005). The population of PRC is expected to peak around 2029 and from then onwards, it will be reduced by 3.4 percent per year. In 2050, the population of PRC is estimated to reach nearly 1.3 billion while the population of India is expected to grow continually until it reaches about 1.7 billion in 2050 . Hence, the labor force of PRC is also expected to reach its peak in around 2020 whereas that of India will continue to grow before reaching nearly 1 billion by 2050 (UN 2011). The demographic dividend of India will support the rapid growth of the country for a long period.

Table 3. Trends in Population in PRC and India: 1960-2010 (Billions of people and \%)

\begin{tabular}{|c|c|c|c|c|c|c|c|}
\hline & \multicolumn{6}{|c|}{ Billions of people } & $\%$ share \\
\hline & 1960 & 1970 & 1980 & 1990 & 2000 & 2010 & 2010 \\
\hline PRC & 0.67 & 0.82 & 0.98 & 1.14 & 1.26 & 1.34 & 19 \\
\hline India & 0.45 & 0.55 & 0.70 & 0.87 & 1.05 & 1.22 & 18 \\
\hline ROW & 1.93 & 2.32 & 2.77 & 3.29 & 3.80 & 4.33 & 63 \\
\hline Total & 3.04 & 3.69 & 4.45 & 5.30 & 6.12 & 6.89 & 100 \\
\hline
\end{tabular}

Source: World Development Indicators (2012)

Table 4. Size of Population by Various Class, 2005 (PPP\$)

\begin{tabular}{|c|c|c|c|c|c|}
\hline & $\$ 2-\$ 4$ & $\$ 4-\$ 10$ & $\$ 10-\$ 20$ & Total & $\$ 20+$ \\
\hline \multicolumn{6}{|c|}{ (\% of the population) } \\
\hline PRC & 33.97 & 25.17 & 3.54 & 62.68 & 0.68 \\
\hline India & 20.45 & 4.15 & 0.45 & 25.05 & 0.10 \\
\hline \multicolumn{6}{|c|}{ Total population (million) } \\
\hline PRC & 442.82 & 328.18 & 46.16 & 817.16 & 8.86 \\
\hline India & 223.82 & 45.41 & 4.90 & 274.13 & 1.14 \\
\hline \multicolumn{6}{|c|}{ Annual Expenditures (billion) } \\
\hline PRC & 233.72 & 311.96 & 95.57 & 641.25 & 37.27 \\
\hline India & 117.11 & 44.39 & 10.96 & 172.46 & 9.95 \\
\hline
\end{tabular}

Note: Based on household survey (PRC- 2005; India- 2005)

Source: ADB (2010)

The middle class will become a key driver of economic growth in Asia with their increasing demand for goods and services as well as their savings and entrepreneurship (ADB 2011). Both India and PRC have sizeable middle class. Based on ADB (2010) estimate of population size by various class, the share of the population of the middle class was at most 4.22 percent for PRC and 0.55 percent for India (Table 4). In 2010, based on the ADB and ADBI (2014) study, the middle class comprised 20 percent of the population in PRC and 5 percent in India (Figure 2). The expansion of the middle class indicates that in a span of five years, around 14 percent of the population in PRC graduated from being a low income class whereas for India, this was around 5 percent. 
Figure 2. Population Composition by Income Class of PRC and India, 2010

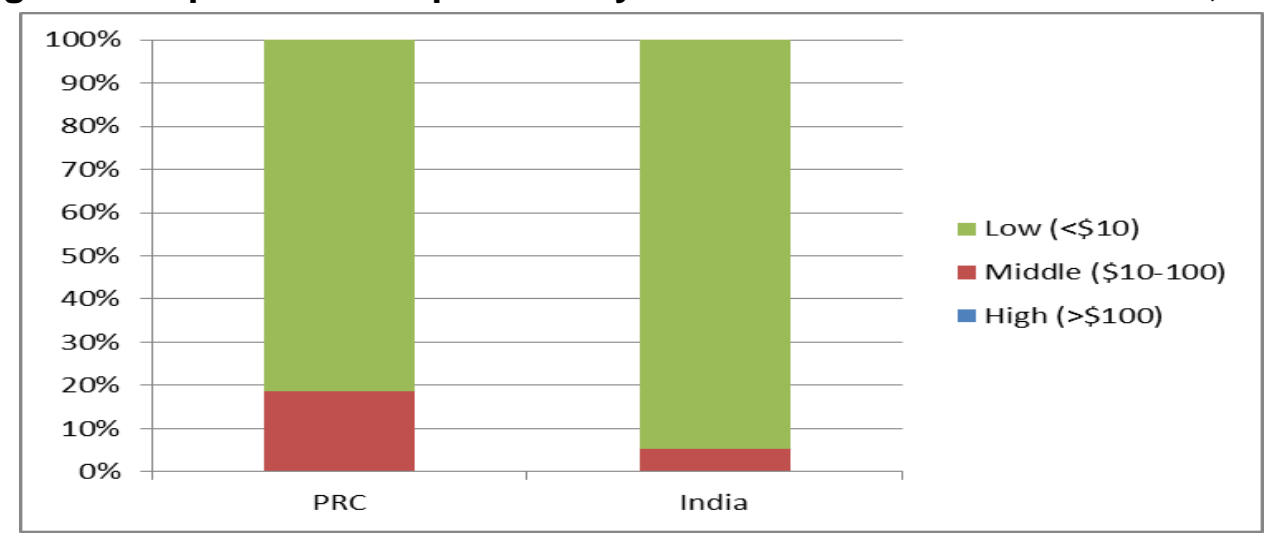

Source: ADB and ADBI (2014)

\subsubsection{Trends in Productivity in PRC and India: Last Two Decades}

Productivity is a key factor to rapid economic expansion. From 1981-2007, total factor productivity (TFP) remained positive for PRC and India, and the growth rates of TFP in both countries were highest during 2001-2007-around 6 percent in PRC and around 2 percent in India. In general, TFP is three times higher in the PRC compared with India and correspondingly, TFP contributed more to GDP growth in PRC than in India across decades from the 1980s (Lee and Hong, 2010). Starting in 2001, the growth in TFP has become the main contributor to the growth in output of PRC, accounting for more than 50 percent of the GDP growth of the said country (Figure 3).

Table 5. Factors of Productivity (annual average growth rate in \%), 1981-2007

\begin{tabular}{|l|c|c|c|c|}
\hline PRC & $\mathbf{1 9 8 1 - 9 0}$ & $\mathbf{1 9 9 1 - 2 0 0 0}$ & $\mathbf{2 0 0 1 - 0 7}$ & $\mathbf{1 9 8 1 - 2 0 0 7}$ \\
\hline GDP & 8.34 & 9.09 & 11.15 & 9.35 \\
\hline GDP per Labor & 5.81 & 7.91 & 10.22 & 7.73 \\
\hline Labor input & 2.53 & 1.18 & 0.93 & 1.61 \\
\hline Education & 0.70 & 1.19 & 0.83 & 0.91 \\
\hline Capital per labor & 5.93 & 8.72 & 9.16 & 7.80 \\
\hline Total factor productivity & 3.02 & 3.72 & 6.06 & 4.07 \\
\hline India & \multicolumn{5}{|c|}{} \\
\hline GDP & 5.39 & 4.74 & 6.76 & 3.51 \\
\hline GDP per Labor & 3.04 & 2.69 & 4.73 & 2.16 \\
\hline Labor input & 2.35 & 2.06 & 2.03 & 0.82 \\
\hline Education & 1.10 & 0.60 & 0.74 & 3.78 \\
\hline Capital per labor & 2.70 & 3.45 & 5.78 & 1.34 \\
\hline
\end{tabular}
Source: Lee and Hong (2010)

From 1981-2000, the increase in capital had the highest contribution to output growth for both the PRC and India. For the period 2001-2007, there was a shift in the economic structure of PRC as the country had started to source most of its growth from TFP, only followed by capital. For the case of India, while capital continued to be main source of its GDP growth, starting in 2001, there was also a shift from labor to TFP as the second greatest contributor to output growth. The contribution to output growth of labor growth is much higher in India than in the PRC but this contribution has been declining for both countries. Meanwhile, the contribution of education, albeit still minimal for both PRC and India, had been higher for the latter than in the former, except in 1991-2000. Based on the latest sources of growth estimate of Zhuang (2011) for 2000 to 2010, the main contributor to GDP growth of both PRC and India was the growth of TFP, only followed by capital (Figure 3 ). 
Figure 3. Contributions to GDP growth (percentage points), 1981-2010

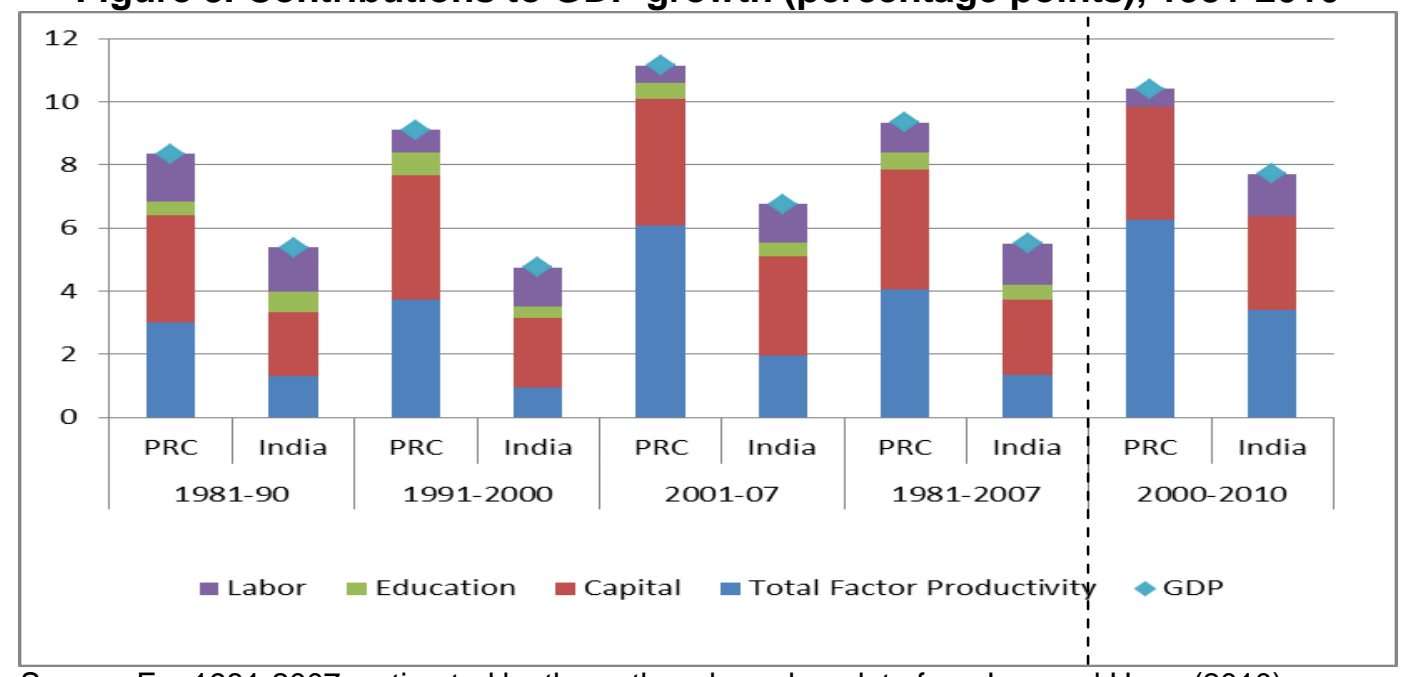

Source: For 1981-2007, estimated by the authors based on data from Lee and Hong (2010)

For 2000-2010 from Zhuang (2011), sources of growth estimate excludes education.

\section{(i) Savings, Capital and Investment}

Both in PRC and India, investment was supported by savings, capital inflows and foreign direct investment (FDI). First, high savings as well as financial repression policies in the PRC have provided cheap finance as well as facilitated capital accumulation in the country (Table 6 , Prasad (2009)). As shown in Table 6, for the period 2000-2008, the savings and investments rates in PRC have been quite high at 45.7 percent and 41.0 percent, respectively, with excess savings. Meanwhile, for the same period in India, the share to GDP of savings was 30.8 percent while that of investment was 31.3 percent, with a minimal negative savings-investment gap. The savings and investments in PRC and India are significant and these contributed in the rapid growth and development of these two countries.

Table 6. Savings and Investment, 2000-2008 (\% of GDP)

\begin{tabular}{|l|c|c|c|}
\hline & $\begin{array}{c}\text { Savings } \\
\text { (S) }\end{array}$ & $\begin{array}{c}\text { Investment } \\
\text { (I) }\end{array}$ & (S-I) \\
\hline PRC & 45.65 & 40.95 & 4.70 \\
\hline India & 30.82 & 31.32 & -0.50 \\
\hline
\end{tabular}

Investment can be funded through domestic savings or through international capital inflows. Figure 4 shows the sources of net capital flows in India and PRC. After 1991, FDI inflows in the PRC has risen significantly when policies that further lowered tariffs and liberalized FDIs were enacted in preparation for the country's accession to World Trade Organization (WTO) in 2001. The involvement of the PRC in the regional production networks as well as its abundant supply of low-wage labor provided multinational corporations the incentive to invest and relocate production in the country (Athukorala 2010).

FDI as a share of GDP is much lower in India compared to PRC. Since India is not deeply integrated with East Asian Regional Production Networks like PRC, the country has not been able to attract large investment from multi-national corporations (MNCs). Moreover, India does not have good quality infrastructure like PRC and this discouraged potential investors to treat the country as a hub for producing goods for exports. Nevertheless, capital inflows in India are well facilitated through the country's stock markets, which are more developed than that in PRC due to the Bombay Stock Exchange that started operations during the British colonial rule (Farell and Lund 2006). 

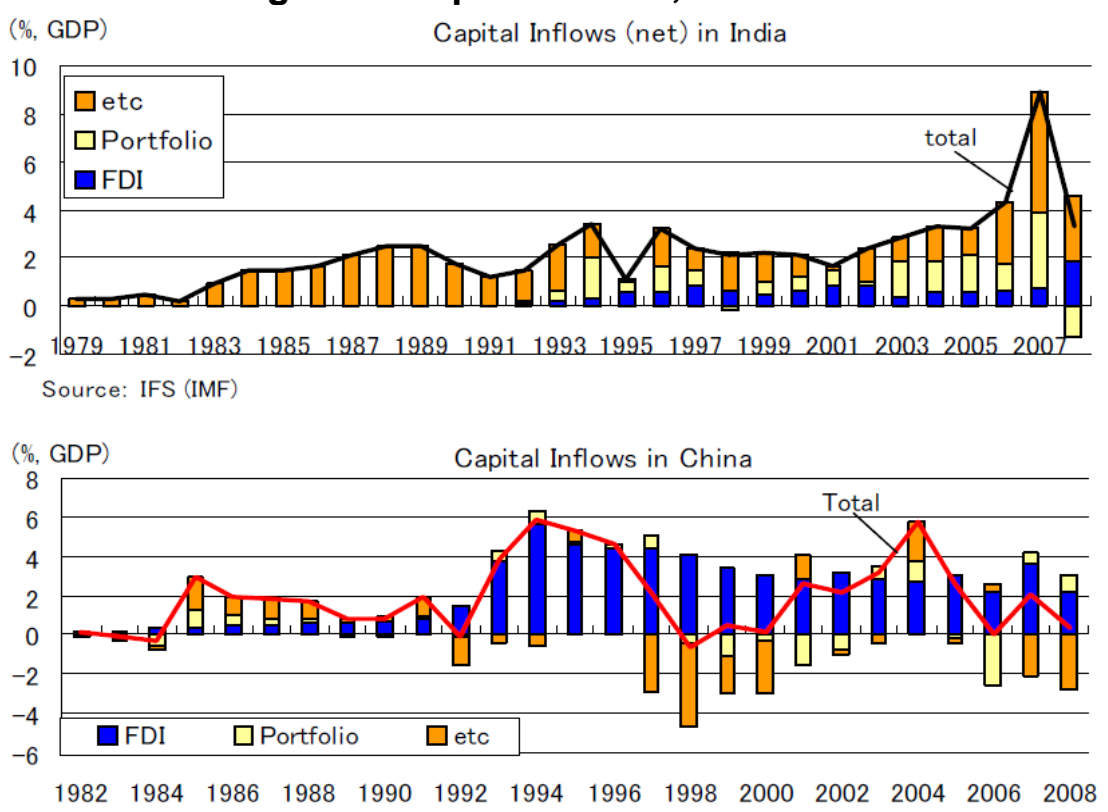

Source: IMF-IFS as cited in Ohta (2010)

Note: Etc implies other sources of capital inflows; China refers to PRC.

\section{(ii) Labor Migration}

Some important factors that contributed to economic growth and development of PRC and India are demographic advantages and related policy reforms which augmented labor supply in growing sectors, particularly in PRC. Labor inputs increased through favorable demographics worked in both countries as evidenced by the rise of production age population ratios, and increasing employment. Table 7 shows that the total labor force has been increasing in both countries since the 1980s. In PRC, the labor force increased from 503 million in 1980 to 783 million in 2009 while in India, it almost doubled from 253 million to 458 million during the same period.

In 2000, around 96 percent of the labor force in PRC and India were employed. In terms of labor participation rate, there is around 20 percentage points difference between PRC and India from 1980-2009. It is worth noting that the female labor participation rate in India is only half of that in PRC almost throughout the whole period. In 2009, in PRC it was 67 percent whereas in India it was only 33 percent. This shows a huge potential for India to increase labor participation rate in the coming years by integrating more females into the labor force.

Increased labor participation and policy reforms caused a shift in the employment composition in both the PRC and India in recent decades. In both countries migration from the rural to the urban sector has filled in the increased demand for low-wage workers in the rapidly growing manufacturing sector in PRC and the robustly expanding service sector in India. From 1990-2005, net rural to urban migration ratios for the PRC and India were 2.4 percent and 2.0 percent respectively (Chan, 2008). The average growth rates of the urban populations in these countries were significantly increasing due mainly to migration rather than to natural birth rates of the total populations. In fact, during the said period, the natural birth rate dropped from 0.8 to 0.5 percent in the PRC and from 1.7 to 1.3 percent in India (Ibid.).

The main reasons behind the internal and rural-urban labor migration in India and PRC are wage, income, and human development differentials. In PRC, the top five receiving regions are the industrially developed coastal provinces Guangdong, Zhejiang, Shanghai, Jiangsu and Beijing. They comprise around 55 percent of the total internal migration in the PRC. This has resulted in rapid industrialization in the coastal region of PRC. Guangdong is considered the "world's factory" which has attracted around 30 percent of the inter-provincial migrants in the last two decades and over 10 million people from 2000 to 2005. 
Table 7. Labor Statistics, 1980-2009

\begin{tabular}{|c|c|c|c|c|c|}
\hline & & 1980 & 1990 & 2000 & 2009 \\
\hline \multirow[t]{2}{*}{ Labor force; total (million) } & PRC & 503.11 & 643.92 & 725.96 & 783.16 \\
\hline & IND & 252.88 & 317.78 & 385.44 & 457.46 \\
\hline \multirow{2}{*}{$\begin{array}{l}\text { Labor participation rate; female (\% of } \\
\text { female population ages } 15+\text { ) }\end{array}$} & PRC & 71.0 & 73.0 & 70.9 & 67.4 \\
\hline & IND & 32.6 & 34.0 & 33.0 & 32.8 \\
\hline \multirow{2}{*}{$\begin{array}{l}\text { Labor participation rate; male (\% of male } \\
\text { population ages } 15+\text { ) }\end{array}$} & PRC & 87.5 & 85.0 & 83.6 & 79.7 \\
\hline & IND & 86.3 & 84.3 & 82.2 & 81.1 \\
\hline \multirow{2}{*}{$\begin{array}{l}\text { Labor participation rate; total (\% of total } \\
\text { population ages } 15+\text { ) }\end{array}$} & PRC & 79.5 & 79.2 & 77.4 & 73.7 \\
\hline & IND & 60.6 & 60.2 & 58.4 & 57.6 \\
\hline \multirow[t]{2}{*}{ employment; total (\% of total labor force) } & PRC & 95.1 & 97.5 & 96.9 & 95.7 \\
\hline & IND & & & 95.7 & \\
\hline
\end{tabular}

$\ldots=$ not available

Source: World Development Indicators 2011/09/09

Table 8. Interprovincial migration in the PRC, 2000-2005 (in thousands)

\begin{tabular}{|c|c|c|c|c|c|}
\hline \multicolumn{3}{|c|}{ Positive Net Migration } & \multicolumn{3}{|c|}{ Negative Net Migration } \\
\hline Area & Net & $\begin{array}{c}\text { Net \% of } \\
\text { Population }\end{array}$ & Area & Net & $\begin{array}{c}\text { Net \% of } \\
\text { Population }\end{array}$ \\
\hline Guangdong & 10,281 & 27.0 & Sichuan & $-3,178$ & -8.4 \\
\hline Zhejiang & 4,021 & 10.6 & Anhui & $-3,165$ & -8.3 \\
\hline Shanghai & 2,650 & 7.0 & Henan & $-3,154$ & -8.3 \\
\hline Jiangsu & 1,963 & 5.2 & Hunan & $-2,827$ & -7.4 \\
\hline Beijing & 1,916 & 5.0 & Hubei & $-2,214$ & -5.8 \\
\hline Fujian & 1,132 & 3.0 & Jiangxi & $-1,977$ & -5.2 \\
\hline Tianjin & 802 & 2.1 & Guangxi & $-1,726$ & -4.5 \\
\hline Others & 676 & 2.0 & Others & $-3,964$ & 10.4 \\
\hline
\end{tabular}

Note: Net\% = Net migration divide by National total of in-migration in \%, *including Chongqing

Source: Chan, 2008 (quoted from Wilson, et. al. (2011).

On the other hand, the top five regions with negative migration are basically less industrialized, inland provinces (Table 8). Thus, the data shows a close correlation between the intensification of industrial restructuring and the pattern of inter-provincial migration, whereby inland provinces have lost proportionately more manufacturing jobs to the coastal provinces (Wilson, Jayanthakumaran, and Verma, 2011). Thus, the economic growth of PRC was enhanced by the development of robust manufacturing sector, supported by effective labor migration policies by the governments.

In contrast, the provinces receiving significant internal migrants in India in 2009 are mainly modern growing provinces with large cities and increasing service sector activities, like Maharashtra, the capital New Delhi, and the coastal state of Goa (Table 9). Particularly, with larger service sector New Delhi received around 24 percent of the internal migrants. On the other hand, the poorer states of Bihar and Kerala have large out-migrations 5.6 percent and 4.4 percent respectively (Wilson, Jayanthakumaran, and Verma, 2011).

Thus, the relaxation of policies related to inter-sectoral and inter-provincial labor migration ensured the continuous, low wage labor supply for the rapidly growing industrial sector and enhanced FDI that supported a manufacturing-led economic growth in PRC. Similarly, the increasing labor force participation due to migration provided support to the development of the service sector in India. 
Table 9. Inter-state migration in India, 2009 (in thousands)

\begin{tabular}{|l|c|c|l|c|c|}
\hline \multicolumn{3}{|c|}{ Prea } & Net & $\begin{array}{c}\text { Net \% of } \\
\text { Population }\end{array}$ & \multicolumn{2}{c|}{ Area } & Net & $\begin{array}{c}\text { Net \% of } \\
\text { Population }\end{array}$ \\
\hline Maharashtra & 3,889 & 4.1 & Uttar Pradesh & $-5,291$ & -3.1 \\
\hline New Delhi & 3,182 & 24.2 & Bihar & $-4,261$ & -5.6 \\
\hline West Bengal & 1,055 & 1.3 & Kerala & $-1,323$ & -4.4 \\
\hline Gujarat & 805 & 1.6 & Tamil Nadu & -884 & -1.4 \\
\hline Harayana & 767 & 3.5 & Andra Pradesh & -654 & -0.9 \\
\hline Chhattisgarh & 640 & 2.8 & Rajasthan & -540 & -0.9 \\
\hline Karnataka & 474 & 1.0 & Orissa & -459 & -1.3 \\
\hline Punjab & 303 & 1.3 & Madhya Pradesh & -410 & -0.7 \\
\hline Chandigarh & 342 & 39.9 & Assam & -124 & -0.5 \\
\hline Goa & 1,874 & 129.9 & J and K & -103 & -1.2 \\
\hline Others & 544 & 3.7 & Others & -483 & -1.7 \\
\hline
\end{tabular}

Source: NSS (2009) in Wilson, et. al. (2011)

\section{(iii) Education}

The contribution of education and vocational training is important in producing a large pool of labor that is able to work in the growing sectors. The same is true for both PRC and India. Both countries benefitted from having educated and well trained labor force which is the result of effective policies taken by both governments in different stages of their development. In particular, vocational training facilitated the effective transfer of labor from the agriculture sector to the more productive manufacturing sector where advanced skills are not necessary in low-technology factories in PRC. On the other hand, the availability of well educated and English speaking labor force facilitated the development of the service sector in India.

Data shows that the PRC and India host the first two largest education systems in the world, as together they contain 45 percent of the world population of primary school-age children (Rao, Cheng, and Narain, 2003). Both countries started building their national education systems under comparable conditions in the late 1940s. During that time, both the PRC and India prioritized higher education. However, starting the mid-1960s, the PRC shifted its policy and focused on primary education and from the 1980 s to the early $21^{\text {st }}$ century, the country rebuilt the foundations of higher education and developed vocational training. Meanwhile, India took the opposite turn and began to give emphasis on primary education (Goldman, Kumar and Liu 2008).

Different policies, strategies, and historical circumstances have led these countries through different routes. The PRC (95 percent in primary and 70 percent in secondary education) has outperformed India (82 percent in primary and 53 percent in secondary education) in terms of enrollment along a broad spectrum of access, quality, and delivery indicators. On the other hand, India enjoys a competitive edge over the PRC in terms of higher education. Recently, India has begun to catch up with the PRC in primary and secondary education, while the PRC has already overtaken India in terms of college enrollment and number of graduates (Goldman, Kumar and Liu 2008).

Table 10. Education achievements, 1990-2010

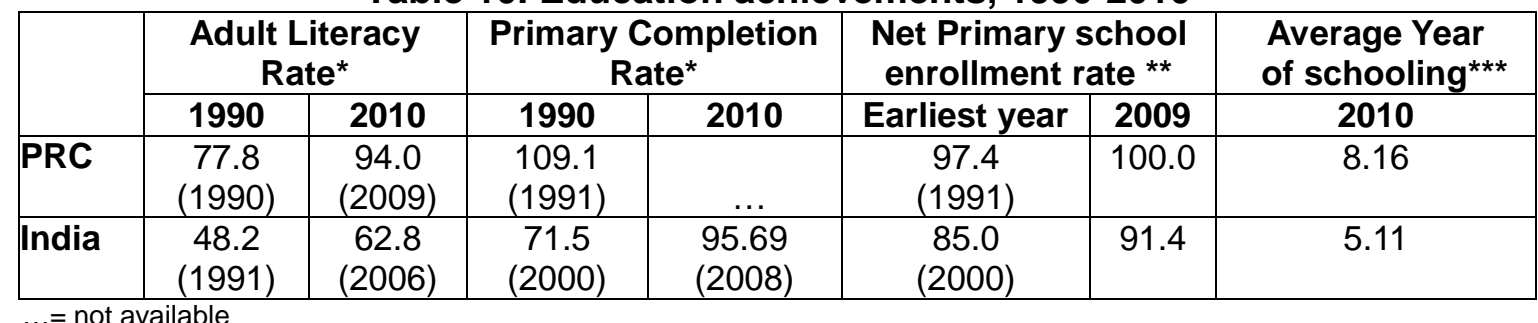

Sources: *World Development Indicators, 2012; **MDG (2011); ***Zhuang (2011) from WDI 
Table 10 shows that the PRC is well ahead of India in terms of primary education completion, enrollment ratio and adult literacy rate. PRC achieved 94 percent adult literacy in 2010 where as for India it was around 63 percent in 2006. Similarly, while total net primary enrolment ratio for both sexes was 97.4 percent in 1991 in PRC reaching 100.0 percent in 2009, it increased from 85 percent in 2000 to 91.4 percent in 2009 in India.

\section{(iv) Role of Technology and Diaspora}

Foreign technology, imitation to innovation and industrial shift played important roles in increasing total factor productivity, particularly in the PRC. When the PRC began its reforms, it started out as a producer of low quality and low technology products. As foreign technology came in along with the inflow of foreign investments, technology transfer was achieved first through imitation, then through innovation. UNDP's Technology Achievement Index ${ }^{1}$ (TAI 2008) shows that the PRC made substantial progress and has been the most successful in bridging gaps with the frontier in 2008. However, with TAl of 0.299 in the said year, the global position of PRC was 45 among 72 countries. The main strength of PRC is its openness and manufacturing capability. Meanwhile, India remains far behind with TAI of 0.201 , positioning the country at 63 among 72 countries. While India is close to the PRC in basic and applied research, it is about twenty years behind the PRC in incremental innovation (Hu 2011).

The influx of foreign technology has driven the increase in productivity in the PRC and India. Foreign technology has helped the PRC in becoming a leading exporter of electronic goods as the country became integrated in the regional production network; foreign technology, particularly advances in telecommunications, has also helped India in developing its ICT sectors. Furthermore, foreign technology has allowed these countries to take the leap from agriculture production to low-medium technology production, especially in electronics in PRC, and information and computer services in India.

Meanwhile, although the diaspora of skilled and well-educated labor, particularly from India, is spurring the debate on "brain drain", overseas Indians are a source of knowledge, resources and expertise, which are supporting innovation in their home country. Having connections with the overseas local community, diasporas facilitate in linking markets of their host countries with their home countries, sometimes by influencing investment decisions in their host countries toward their home countries (Devane in Kuznetsov 2006). The same is done by overseas Chinese who are linking business opportunities from developed countries to their home country.

In addition, these diasporas are contributing to the development of the PRC and India by sending large remittances. The share of workers' remittances and compensation of employees to GDP in India more than doubled from 1.5 percent in 1980 to 3.2 percent in 2010, In PRC, the share also increased from 0.1 percent in 1985 to 0.9 percent in 2010 (Table 11).

Table 11. Workers' remittances and compensation of employees, received $1980-2010$ (\% of GDP)

\begin{tabular}{|l|r|r|r|r|r|r|r|}
\hline & \multicolumn{1}{|c|}{1980} & \multicolumn{1}{|c|}{1985} & \multicolumn{1}{|c|}{1990} & \multicolumn{1}{c|}{1995} & \multicolumn{1}{c|}{$\mathbf{2 0 0 0}$} & \multicolumn{1}{c|}{$\mathbf{2 0 0 5}$} & \multicolumn{1}{c|}{$\mathbf{2 0 1 0}$} \\
\hline PRC & $\ldots$ & 0.09 & 0.05 & 0.12 & 0.40 & 1.04 & 0.89 \\
\hline India & 1.45 & 1.04 & 0.73 & 1.70 & 2.71 & 2.65 & 3.21 \\
\hline
\end{tabular}

Source: World Development Indicators (2012), $\ldots=$ not available

Other factors that aided in output growth of PRC and India are expansion of exports, domestic deregulation and liberalization of markets. These policies shall be discussed in further detail in the subsequent sections.

\footnotetext{
${ }^{1} \mathrm{TAl}$ is a measure of an economy's overall technological development that ranks countries on a comparative global scale. It is calculated based on the average of four component indices: technology creation, diffusion of old technology, diffusion of new technology and human capital. For each of the four component indices, two indicators are used to construct the index. Countries with TAl above 0.5 are termed as leaders; $0.35-0.49$ potential leaders; $0.20-0.34$ dynamic adopters; and below 0.20 marginalized.
} 


\subsection{Achievements in Economic Development}

The major indicators of development include income indicators (e.g., per capita GDP and poverty reduction) and non-income indicators (e.g., quality of life-Human Development Index). In terms of development, both PRC and India became middle income countries in four decades. Along with economic growth, a rise in GDP per capita is apparent in both India and the PRC (Table 12). While India started with 50 percent higher per capita GDP compared to PRC in 1950 , the per capita GDP of both countries were almost the same in 1970, but in 2010, the per capita GDP of PRC was more than three times that of India (Table 12). Within four decades, per capita GDP rose significantly in both countries, but the rate of increase in PRC was much faster.

Table 12. GDP per capita of PRC and India, 1950-2010 (current US\$)

\begin{tabular}{|l|l|l|l|l|l|l|l|l|l|l|}
\hline Country & $\mathbf{1 9 5 0}$ & $\mathbf{1 9 7 0}$ & $\mathbf{1 9 7 5}$ & $\mathbf{1 9 8 0}$ & $\mathbf{1 9 8 5}$ & $\mathbf{1 9 9 0}$ & $\mathbf{1 9 9 5}$ & $\mathbf{2 0 0 0}$ & $\mathbf{2 0 0 5}$ & $\mathbf{2 0 1 0}$ \\
\hline PRC & 101.0 & 111.8 & 175.9 & 193.0 & 291.8 & 314.4 & 604.2 & 949.2 & $1,731.1$ & $4,433.0$ \\
\hline India & 154.0 & 114.7 & 161.1 & 270.8 & 301.6 & 373.8 & 380.1 & 450.4 & 731.7 & $1,375.4$ \\
\hline
\end{tabular}

Source: World Development Indicators (2012)

Both countries also performed remarkably in poverty reduction along with rapid increase of GDP per capita. Consistent with the rapid increase in per capita income of PRC, a sharper decline in poverty is observed in the country relative to India (Table 13). In terms of $\$ 1.25$ a day poverty line, poverty incidence in PRC fell from around 84 percent in the 1980 s to 13.1 percent in 2008. Meanwhile, in India, this fell from 60 percent in the late 1970s to 32.7 percent in 2010. The poverty incidence in India is about 3 times that of PRC at $\$ 1.25$ per day but around twice at $\$ 2.0$ per day (Table 13). This analysis shows that growth in GDP per capita and poverty incidence are strongly associated (Figure 5).

Table 13. Poverty by Headcount Index, 1981-2010 (\% of population)

\begin{tabular}{|c|c|c|c|c|c|c|c|c|c|c|}
\hline \multicolumn{10}{|c|}{ Living below \$1.25 a day } & \\
\hline & $\mathbf{1 9 8 1}$ & $\mathbf{1 9 8 4}$ & $\mathbf{1 9 8 7}$ & $\mathbf{1 9 9 0}$ & $\mathbf{1 9 9 3}$ & $\mathbf{1 9 9 6}$ & $\mathbf{1 9 9 9}$ & $\mathbf{2 0 0 2}$ & $\mathbf{2 0 0 5}$ & $\mathbf{2 0 0 8}$ \\
\hline PRC & 84.0 & 69.4 & 54.0 & 60.2 & 53.7 & 36.4 & 35.6 & 28.4 & 16.3 & 13.1 \\
\hline India & 59.8 & $\begin{array}{c}55.5 \\
(1983)\end{array}$ & $\begin{array}{c}53.6 \\
(1988)\end{array}$ & 51.3 & $\begin{array}{c}49.4 \\
(1994)\end{array}$ & 46.6 & 44.8 & 43.9 & 41.6 & $\begin{array}{c}32.7 \\
(2010)\end{array}$ \\
\hline \multicolumn{8}{|c|}{ Living below \$2.00 a day } \\
\hline PRC & $\mathbf{1 9 8 1}$ & $\mathbf{1 9 8 4}$ & $\mathbf{1 9 8 7}$ & $\mathbf{1 9 9 0}$ & $\mathbf{1 9 9 3}$ & $\mathbf{1 9 9 6}$ & $\mathbf{1 9 9 9}$ & $\mathbf{2 0 0 2}$ & $\mathbf{2 0 0 5}$ & $\mathbf{2 0 0 8}$ \\
\hline India & 86.6 & $\begin{array}{c}84.8 \\
(1983)\end{array}$ & $\begin{array}{c}83.8 \\
(1988)\end{array}$ & 82.6 & $\begin{array}{c}81.7 \\
(1994)\end{array}$ & 79.8 & 78.4 & 77.5 & 75.6 & $\begin{array}{c}68.7 \\
(2010)\end{array}$ \\
\hline
\end{tabular}

Source: World Bank, Chen-Ravillion (2008); World Development Indicators (2012)

Moreover, an improvement in the quality of life has also been observed along with economic growth. The Human Development Index $(\mathrm{HDI})^{3}$ of both PRC and India showed a remarkable improvement. As indicated in Figure 6, the HDI levels of PRC and India in the 1980s were not significantly different. However, in a span of thirty years, the HDI of PRC increased from 0.368 to 0.663 while that of India went up from 0.320 to 0.519 . The greater improvement in the HDI of the PRC is reflective of the higher economic growth that the country has achieved compared to India during the same period.

Notwithstanding, a comparative analysis of overall HDI ranking shows that PRC and India still rank way behind with other major world economies in 2010 (Figure 7). In the said year, major economies like the United States ranked $6^{\text {th }}$, Russian Federation was at $58^{\text {th }}$ and Brazil at $59^{\text {th }}$, higher than the ranks of PRC and India at $75^{\text {th }}$ and $100^{\text {th }}$, respectively. It is notable that while

\footnotetext{
2 Swami (2003)

${ }^{3}$ Human Development Index (HDI) is a composite index that measures a country's average achievements in three basic aspects of human development: longevity, knowledge, and a decent standard of living. Longevity is measured by life expectancy at birth; knowledge is measured by a combination of the adult literacy rate and the combined primary, secondary, and tertiary gross enrollment ratio; and standard of living is measured by GDP per capita.
} 
the $\mathrm{HDI}$ of the PRC is consistently higher than that of India, the country still consistently lags behind other emerging economies like Brazil and Russia, albeit it is better off compared to South Africa. This calls for the formulation and implementation of appropriate policies for enhancing further the quality of life along with enhancing income level in PRC and India.

Figure 5. GDP per Capita and Poverty Incidence, 1981-2008

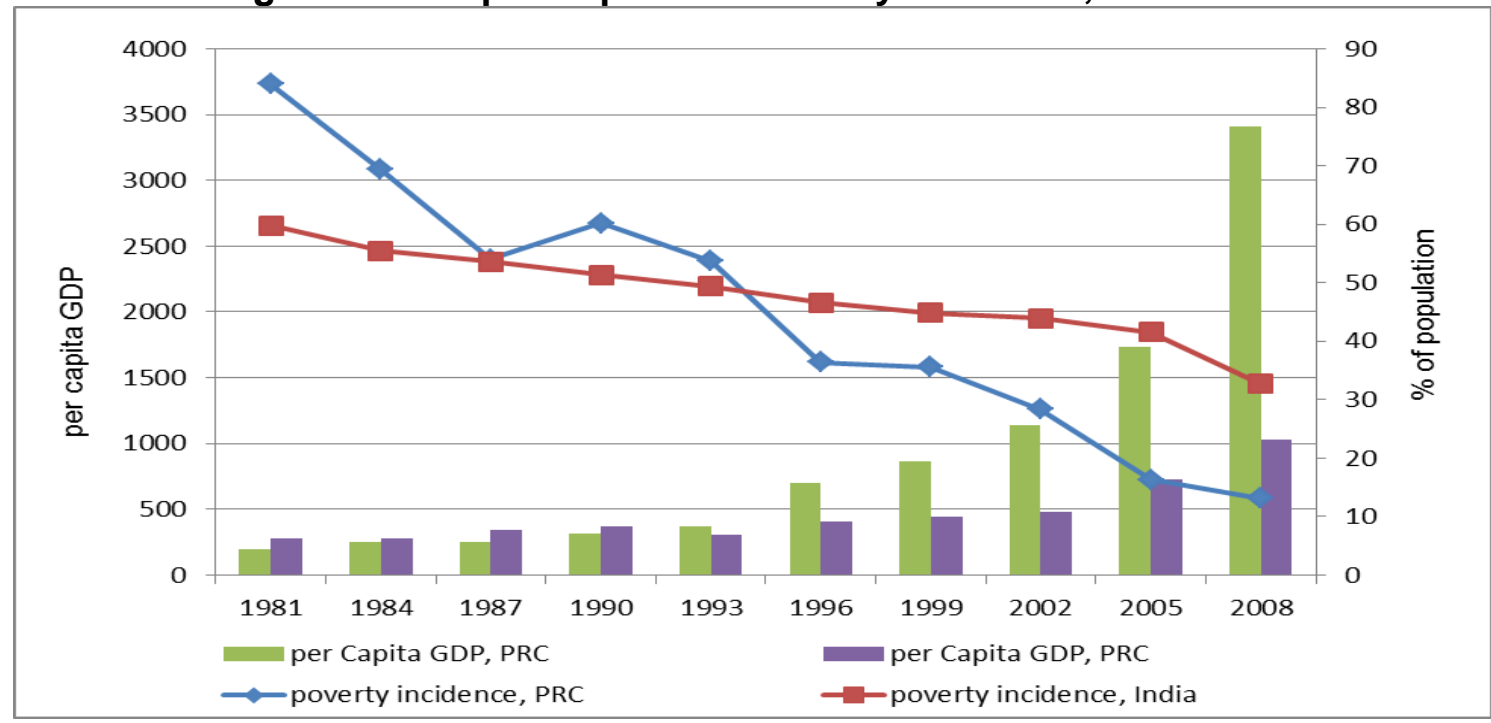

Source: Poverty- Chen and Ravillion 2008, GDP per capita- World Development Indicators 2012

Figure 6. Human Development Index for Major Economies, 1980-2010

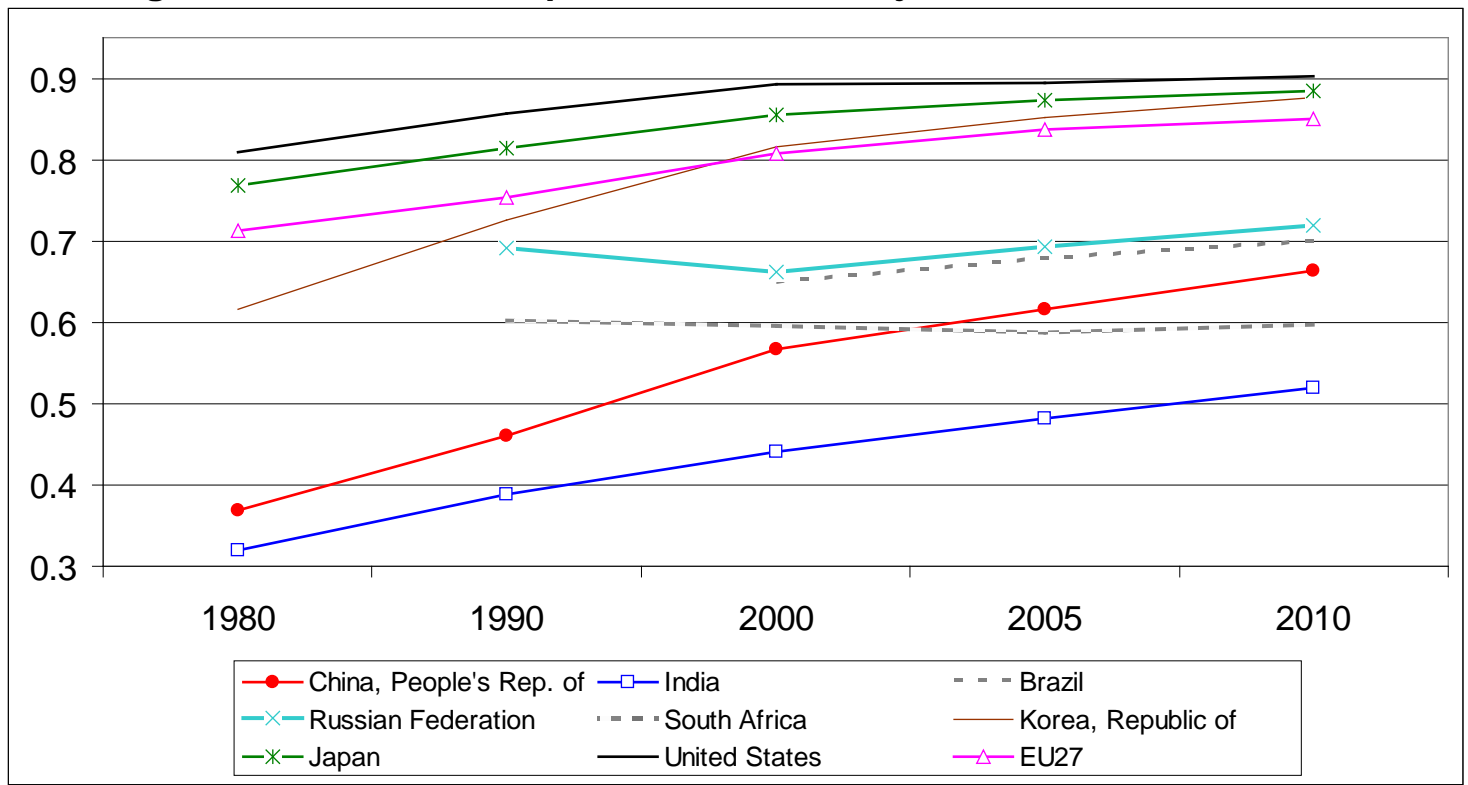

Source: UNDP Human Development Indicators (2010)

\subsection{Drivers of growth}

What is interesting about these two Asian giants is that while both countries experienced rapid economic growth in recent decades, their economic stories are quite different. Prior to reforms, the economies of PRC and India were primarily based on the agricultural sector until 1980scomprising about a third of the economies of PRC (30.17\%) and India (35.70\%) in 1980 (Figure 8). As other sectors develop, it then declined to a third eventually reaching 10 percent of the economy in the PRC and by more than half 18 percent in India in 2009.

However, this does not undermine the importance of the agriculture sector since 47 percent and 57 percent of the population in PRC and India, respectively are still employed in that sector 
in 2004 (Bosworth and Collins 2007). At the same time, the economies of the PRC and India have entered a higher level of economic development as the value added contributions of services and manufacturing have also been increasing. Thus, economic growth and development in PRC and India is driven by both supply side and demand side factors influenced by effective reforms in agricultural, manufacturing, financial and public sectors.

\section{(i) Supply-side: Manufacturing (PRC) vs. Services (India)}

Industrialization played an important role in the economic growth of PRC as it did not only provide higher productivity work compared with agriculture but it also boosted the demand for locally produced products through exports. It also facilitated in significantly reducing poverty in PRC by moving labors from low-wage and low-productivity agriculture sector to the high-wage and high productivity manufacturing sector. Since 1991, the industry sector has led the economic growth of PRC, outpacing the growth of the services sector (Figure 7). In 2011, the industry (or manufacturing) sector, which comprised 47 percent of GDP of PRC remained larger (almost twice) than that of India, which took 26 percent of Indian output. In recent years, the PRC is starting to move from the manufacturing sector into expanding the services sector. This is apparent with the almost doubling of the share to GDP of the service sector from 22 percent in 1980 to 43 percent in 2011 and the slight reduction in the share to GDP of the manufacturing sector from 48 percent to 47 percent in the same period.

Figure 7. Sectoral Value Added Growth Rate, 1991-2011

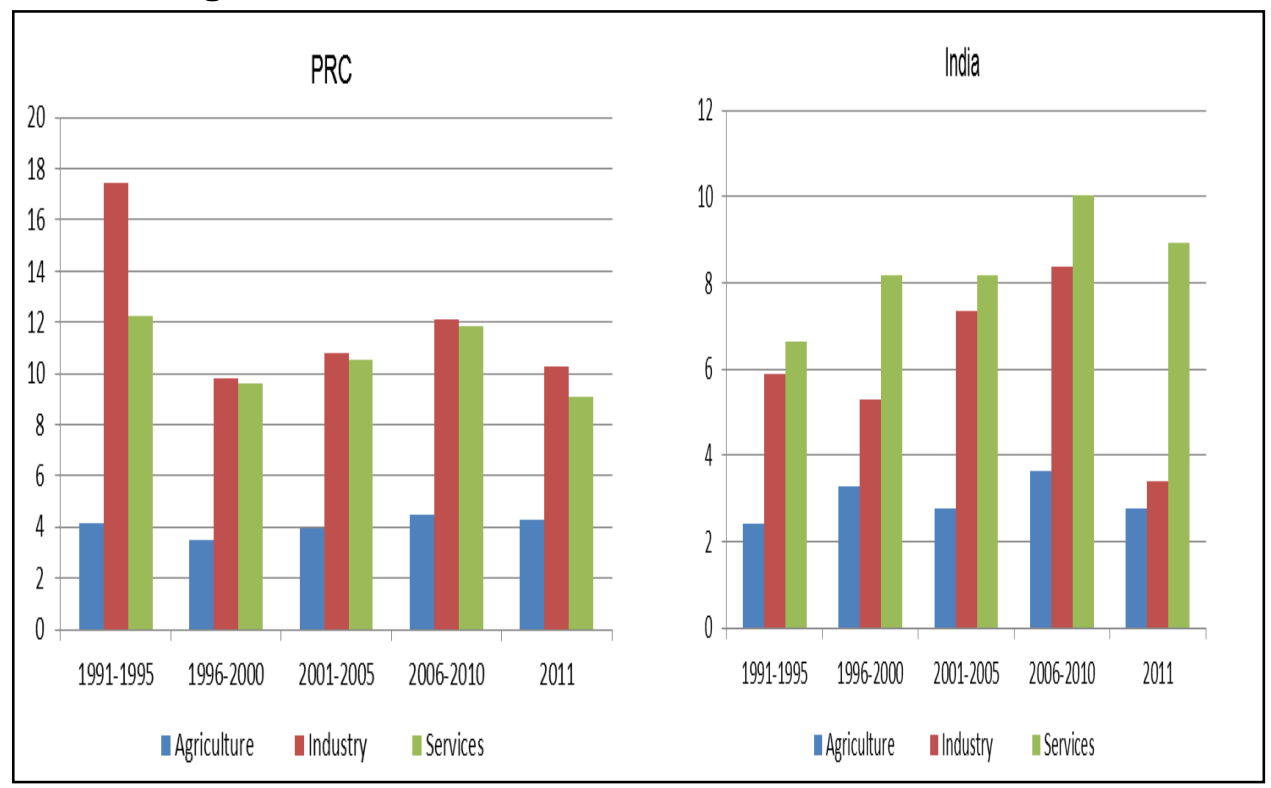

Source: World Development Indicators (2012)

Meanwhile, instead of developing the manufacturing sector after moving from an agricultural economy, as expected in typical developmental economic models, economic growth in India has been driven by the service sector. Since 1991, Indian services sector grew faster than the industry sector (Figure 8). The country benefited from the global advances in telecommunications, its well-educated English-speaking labor force and the Western acceptance of the business process outsourcing model in an increasingly competitive international market. The economic growth and development of India is led by the services sector, with its higher value added share in GDP (Figure 9), which increased from 40 percent in 1980 to 56 percent in 2011. Recently, India has also been improving the share to GDP of its manufacturing sector, which went up from 24 percent in 1980 to 26 percent in 2011. 
Figure 8. Sectoral Value Added Share in GDP, 1960-2011

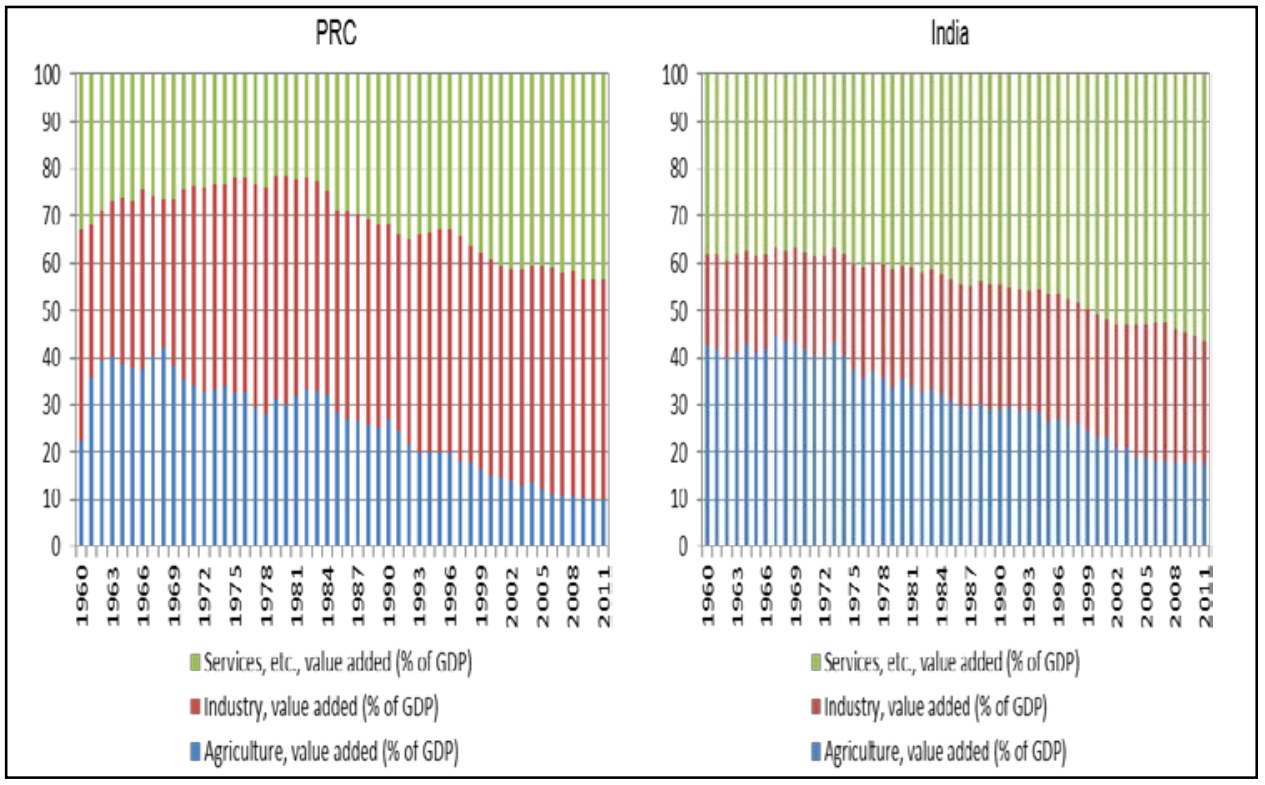

Source: World Development Indicators (2012)

\section{(ii) Demand Side: Investment and net export (PRC) vs. Consumption (India)}

Analysis of demand side drivers of growth shows that the role of private consumption remains significant in both countries throughout the years. The net exports and investment accounted for more than half of the GDP growth of PRC in 2011. As a share of GDP, the net exports increased from -0.4 percent in 1980 to 4.1 percent in 2011 whereas investment increased from 35.2 percent in 1980 to 48.4 percent in 2011. Meanwhile, the shares of government consumption (from $14.9 \%$ to $13.1 \%$ ) and private consumption (from $50.3 \%$ to $34.4 \%$ ) to output decreased during the same period (Figure 9).

Figure 9. Breakdown of Demand, 1970-2011

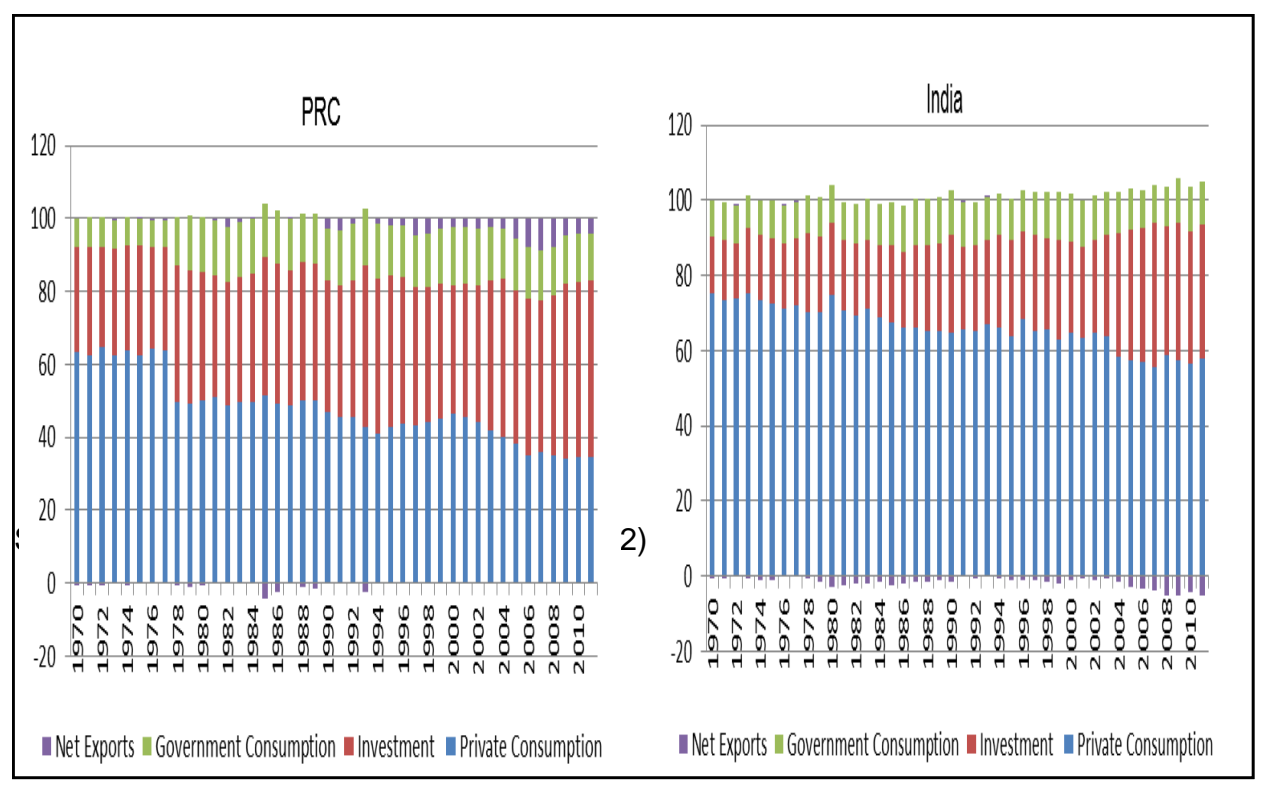

Source: World Development Indicators (2012)

In contrast, private consumption still plays a big role in the economy of India. In the 1960s, it comprised more than 70 percent of India's GDP. While this figure as a proportion of GDP has declined in recent years, it still contributed more than 50 percent of the total Indian output in 2011. From 1980 to 2011, the share to GDP of government consumption increased slightly from 10.1 percent to 11.7 percent while the portion of investment to total output increased significantly from 19.2 percent to 35.5 percent in India. However, the share of net exports to 
Furthermore, the share of consumption to GDP in India is one of the highest among other emerging Asian economies except for Philippines whose the share of private consumption to GDP has been more than 70 percent in the Philippines. The study likens India's consumption with other developed countries. Consumption contributed to more than half of GDP growth in India from 1995 to 2005, similar to Japan which was 51 percent and higher than PRC's at above 30 percent. Consumption is further fueled by the increased inflow of remittances as discussed earlier, particularly for India. The remittances sent by Indian nationals abroad do not only stimulate the economy of India, but also support the proliferation of micro and small enterprises in the country (McKinsey, 2007).

\section{(iii) Role of Agriculture Employment Reform}

Agricultural employment reform supported the development of modern sectors in both India and the PRC. In the past, the agriculture sectors of both countries were characterized by price distortions, which have kept food and agriculture prices low (Schiff and Valdez 1992). Earnings in the agriculture sector are also much lower due to price distortions caused by government monopoly in purchasing agriculture products below the international price (Fan, Chan-Kang, and Mukherjee 2005). This has also helped in keeping wages low in the manufacturing sector since food comprises a big portion of the expenditure of low income earners. Meanwhile, the insufficient infrastructure in rural areas and the lack of access to capital have undermined labor productivity in the agriculture sector. This has encouraged rural workers to find better paying work in the manufacturing sector where labor productivity is also higher.

Table 14. Employment by Industry (percent of total employment), 1978-2010

\begin{tabular}{|c|c|c|c|c|c|}
\hline & & Primary & Secondary & Tertiary & Total \\
\hline \multirow{2}{*}{1978} & PRC & 71 & 17 & 12 & 100 \\
\cline { 2 - 6 } & India & 71 & 13 & 16 & 100 \\
\hline \multirow{2}{*}{1993} & PRC & 56 & 22 & 21 & 100 \\
\cline { 2 - 6 } & India & 64 & 15 & 21 & 100 \\
\hline \multirow{2}{*}{2004} & PRC & 47 & 23 & 31 & 100 \\
\cline { 2 - 6 } & India & 57 & 18 & 25 & 100 \\
\hline $\mathbf{2 0 0 8}$ & PRC & 40 & 27 & 33 & 100 \\
\hline $\mathbf{2 0 1 0}$ & India & 51 & 22 & 27 & 100 \\
\hline
\end{tabular}

Source: China Data Center and CSY; India National Accounts; India NSSO in Bosworth and Collins (2007) For 2008 and 2010, World Development Indicators (2012)

The implementation of reforms in agriculture sector employment has helped in effectively transferring labors from primary sector to secondary sector in both countries. In the late 1970s, the share of population employed in the primary sector was more than 70 percent in both countries. In 2008 and 2010, these shares were reduced to about half, 40 percent in the PRC and 51 percent in India, respectively.

Meanwhile, the contribution of tertiary sector to employment significantly increased for both countries, from 12 percent in 1978 to 33 percent in 2008 for PRC and from 16 percent in 1978 to 27 percent in 2010 for India (Table 14). In the case of the PRC, the movement of labor was facilitated by the relaxation of the 'Hukou' registration system ${ }^{4}$ in the mid-1980s (Fan, Chan-Kang, and Mukherjee 2005). Thus, with reforms in agricultural sector employment, the secondary and tertiary sectors expanded. However, in 2008, agriculture was still the main source of employment (40\%) in PRC, despite the low value added share (10\%) of this sector in the PRC's economy. The same is the case for India in 2010, as the said sector employs more than half of the total employment in the country while its value added share is less than one-fifth of the Indian economy. Meanwhile, the services sector served as the second highest

\footnotetext{
${ }^{4}$ Hukou registration system is the residency registration system adopted in PRC in 1958 to restrict migration of peasant from the countryside to the city
} 
source of employment for both the PRC and India, although the industry sector accounted for bulk of the PRC's GDP. The industry sector accounted for about 50 percent and 30 percent of the respective total GDP of PRC and India but the share of the sector's employment is less than 30 percent for both countries (Figure 10).

Figure 10. Distribution of Employment by Sector of PRC (2008) and India (2010)

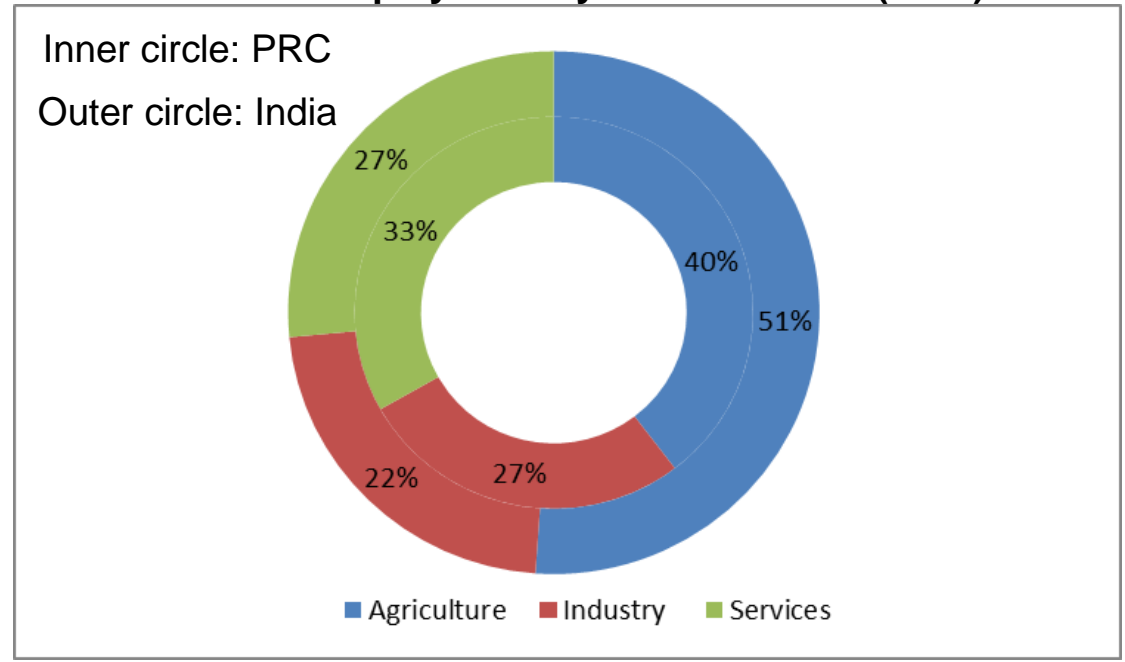

Source: World Development Indicators (2012)

\section{(iv) Role of the Financial System Reforms}

Both the PRC and India implemented various policies and reforms in the financial system to support growth and development. However, while they have made successful reforms in the banking sector through liberalization, institution, and structural change, the privatization of financial institutions, particularly banking sector still have a long way to go (Roland 2006). Nevertheless, there are several private domestic and foreign banks as well as competing pubic sector banks in India, which somehow have stimulated competition in the sector. In contrast, public sector banks in the PRC have a high market concentration. The dominance of state ownership of banks consequently has implications on efficiency and costs of financial intermediation in this country.

In order to support the growing banking system in PRC, the modern central bank was founded through the People's Bank of China (PBC) in 1984. With its establishment, the PBC has taken over the implementation of monetary policy and financial system supervision in the PRC (Cho 1999). This is quite late compared to the establishment of central bank in India, the Reserve Bank of India (RBC), in 1935. The long history of India in central banking as well as the experience of the country with the balance of payments crisis in 1991 had made the banking sector in India better in financial reforms compared to PRC (Dobson 2007).

The implemented reforms in the banking sectors of PRC and India have enhanced the capacity of their banks as the major financial intermediary for supporting their growth and development. In PRC, the banking system accounts for around 70 percent of the total financial assets (McKinsey, 2007). Meanwhile, the PRC exceeds India in all categories in terms of magnitude, namely, bank deposits, private credit by deposit money, stock market capitalization and private bond market capitalization.

The deposit money in banks remains to be the largest source of financing for development in the two countries. From 1986 to 2010, bank deposits in these countries have been increasing along with private credit by deposit money (Figure 12). In particular, the shares to GDP of bank deposits soared from 39.4 percent in 1986 to 157.1 in 2010 in PRC and from 33.1 percent to 67.1 percent for the same period in India.

The increase in stock market capitalization in both countries was also huge. In terms of share to GDP, stock market capitalization expanded from around 12 percent in 1990 to around 94 
percent in 2010 for India and from 0.5 percent in 1991 to 81 percent in 2010 for PRC. However, it is worth noting that while the stock markets have expanded in PRC and India in recent years, these have been very volatile. For instance, after spiking in 2007, stock prices plummeted in 2008 at the advent of the global financial crisis.

Meanwhile, other forms of financial intermediation also increased in both countries for the period 1990 to 2010. For instance, the share of private bond market to GDP went up for the said period from 2.9 percent to 21.3 percent for PRC and from 0.3 percent to 5.7 percent for India (Figure 11).

\section{Figure 11. Structure of Financial Intermediation in PRC and India, 1981-2010}

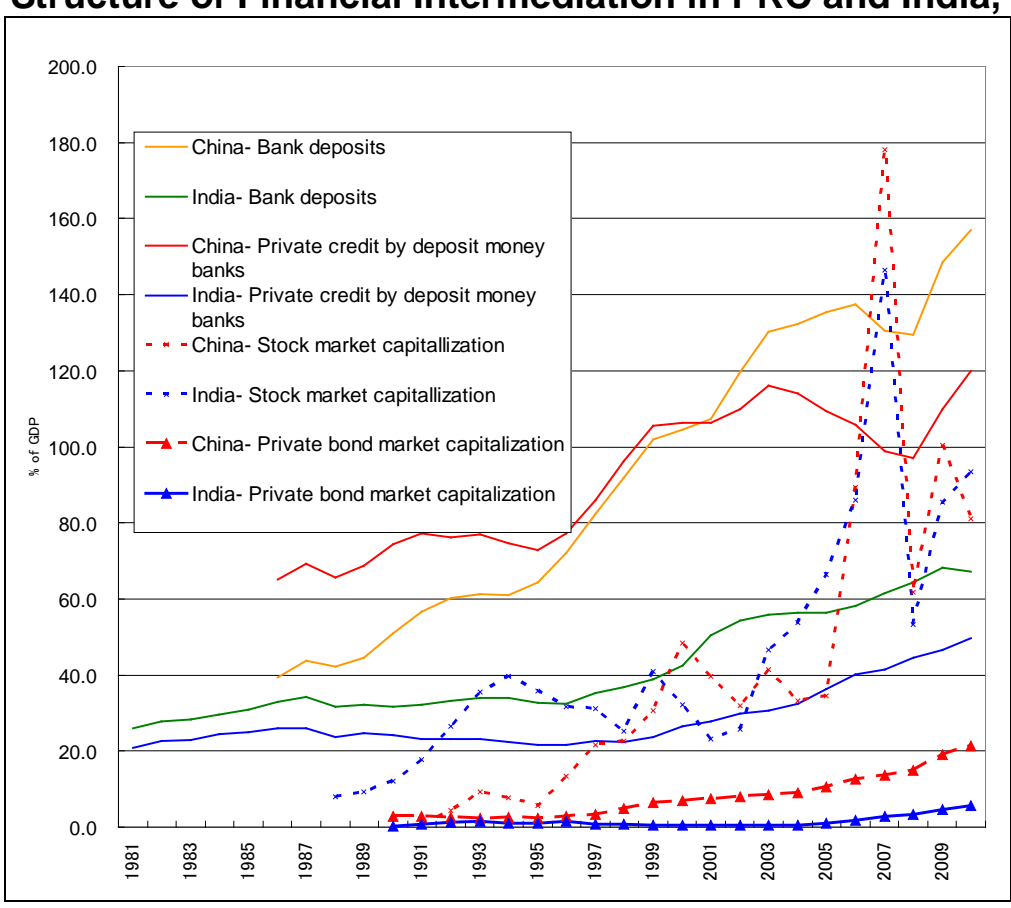

Source: CEIC Data Company, IMF International Financial Statistics, and BIS Quarterly Review (July 2011) (for bond market)

Table 15. Distribution of Bank Credit by Industry, PRC (Top 5 Industries, \% of Total), 2009-2010

\begin{tabular}{|l|c|c|}
\hline \multicolumn{1}{|c|}{ Industry } & $\mathbf{2 0 0 9}$ & $\mathbf{2 0 1 0}$ \\
\hline Transportation & 20.2 & 21.1 \\
\hline Manufacturing & 20.0 & 20.0 \\
\hline Utilities & 13.4 & 12.1 \\
\hline Real Estate & 10.7 & 10.9 \\
\hline $\begin{array}{l}\text { Wholesale, retail and } \\
\text { lodging }\end{array}$ & 6.6 & 8.3 \\
\hline
\end{tabular}

Note: Data for the largest commercial bank in PRC is used since aggregate data for the banking sector from the People's Bank of China is not available.

Source: Industrial and Commercial Bank of China Limited (2011)

The availability of easy financing is crucial for industrial development. In terms of industry classification of domestic credit, majority of the loans provided in 2009 and 2010 in PRC went to manufacturing (20\%) and non-tradable sectors such as transportation (20\%), utilities (13\%), and real estate (11\%) (Table 15). Meanwhile, infrastructure investment (26\%) was on top of the gross bank credit deployment in India, followed by heavy industries such as iron and steel (9\%), chemicals (7\%) and fuel production (6\%) (Table 16).

The developments in the financial intermediation in the PRC and India have allowed the utilization of available savings in these countries into productive investments. However, while the government bond markets have already developed significantly, domestic corporate markets are still underdeveloped and are still needed to be strengthened to reduce the high dependence of these economies on bank financing. Moreover, reforms in the financial system 
of PRC and India still show signs of weaknesses. For instance, the provision and availability of formal financial sector is still considered to be insufficient as evidenced by the presence of informal lending sectors in these countries. McKinsey (2007) estimated that India (30\%) has a larger informal financial sector compared to PRC (5\%).

Table 16. Distribution of Bank Credit by Industry, India (Top 5 Industries, \% of Total), 2009-2010

\begin{tabular}{|l|c|c|}
\hline \multicolumn{1}{|c|}{ Industry } & $\mathbf{2 0 0 9}$ & $\mathbf{2 0 1 0}$ \\
\hline Infrastructure & 26 & 29 \\
\hline Iron and Steel & 9 & 10 \\
\hline Other Industries & 10 & 10 \\
\hline $\begin{array}{l}\text { Chemicals, Dyes, Paints, } \\
\text { etc. }\end{array}$ & 7 & 7 \\
\hline Petroleum & 6 & 6 \\
\hline
\end{tabular}

Source: Reserve Bank of India (2011)

\section{(v) Role of Public Finance}

The health of the fiscal sector is important for the future prospects of the country. While government consumption plays a role in stimulating the economy, the presence of a large government deficit may inhibit government investment in key social areas. Table 17 shows central and local government fiscal balance data for India and the PRC. Both countries have significantly utilized public finance at the center and state levels to help boost growth and development. Data for the PRC shows that the ratio of fiscal balance to GDP of the central government has turned from a surplus (0.01\%) in 2002 into a deficit $(-0.02 \%)$ in 2010 . In the local level, it has always been negative, but the ratio of deficit to GDP doubled from 0.04 percent in 2002 to 0.08 percent in 2010 . Notwithstanding, the resulting negative consolidated fiscal balance of PRC in 2010 remains small compared to the economic size of the country.

Table 17. Fiscal Balance: Centre, States/Local and Consolidated (\% of GDP), 2002-2010

\begin{tabular}{|l|c|c|c|c|c|c|}
\hline & \multicolumn{3}{|c|}{ PRC } & \multicolumn{3}{c|}{ India } \\
\hline Year & Centre & Local & Consolidated & Centre & States & Consolidated \\
\hline $\mathbf{2 0 0 2}$ & 0.01 & -0.04 & -0.03 & -6.7 & -4.21 & -10.54 \\
\hline $\mathbf{2 0 0 3}$ & 0.03 & -0.06 & -0.03 & -6.04 & -4.16 & -9.71 \\
\hline $\mathbf{2 0 0 4}$ & 0.03 & -0.05 & -0.02 & -4.62 & -4.38 & -8.65 \\
\hline $\mathbf{2 0 0 5}$ & 0.04 & -0.05 & -0.01 & -3.9 & -3.32 & -7.26 \\
\hline $\mathbf{2 0 0 6}$ & 0.04 & -0.05 & -0.01 & -4.73 & -2.44 & -7.26 \\
\hline $\mathbf{2 0 0 7}$ & 0.05 & -0.05 & -0.01 & -4.27 & -1.81 & -6.32 \\
\hline $\mathbf{2 0 0 8}$ & 0.06 & -0.06 & 0.01 & -3.11 & -1.51 & -4.65 \\
\hline $\mathbf{2 0 0 9}$ & -0.01 & -0.07 & 0.00 & -8.2 & -2.4 & -10.62 \\
\hline $\mathbf{2 0 1 0}$ & -0.02 & -0.08 & -0.02 & -6.61 & -2.83 & -9.43 \\
\hline
\end{tabular}

Source: (1) For India : Public Finance Statistics, Ministry of Finance, Government of India up to (2009/10) in Economic Outlook 2011-2012 (ii) For PRC: CEIC (2011)

Note: 1 . Fiscal deficit= Revenue- Expenditure 2. *Fiscal deficit includes off budget liabilities

On the other hand, India has large fiscal deficits both for the central government and the states. From 2002 to 2010, fiscal deficits of the central government of India remained persistently high at around 6 percent of GDP, while for Indian states, it decreased from 4.2 percent to 2.8 percent during the same period. Consequently, the consolidated fiscal deficit of India remained quite high around these years. This persistent large deficit of India may undermine the capability of the country to invest in social sector and infrastructure. 


\subsection{Trade and FDI Performance}

\section{(i) Trade}

The outward policy of the PRC and India has stimulated trade and has encouraged investment inflows in both countries. India became a member of WTO in 1995 while PRC joined in 2001. Trade has increased for both countries, especially for the PRC after joining WTO in 2001. During 1970s, trade comprised less than 10 percent of GDP for the PRC and India, when both were relatively closed economies. The trade of PRC witnessed a rapid growth starting in 1978 when the country began to open up its markets. In 2011, the trade to GDP ratio of PRC reached 59 percent, a significant increase from 22 percent in 1980. The same was the case for India as its trade more than tripled from 1990 to 2011, after the country opened up its market in 1991. The increase in trade openness of India is reflected by the jump in its trade to GDP ratio from 15 percent in 1980 to 54 percent in 2011 (Figure 13). Corresponding to the increase in trade openness of the PRC and India is the greater share of exports to total output of both countries in the same period. The share of exports to GDP is greater in PRC than in India as the portion in the PRC was about one-third while in India was around one-fifth, on the average (Figure 12).

Figure 12. Trade Openness and Export Dependence of PRC and India, 1970-2011

Trade \% of GDP

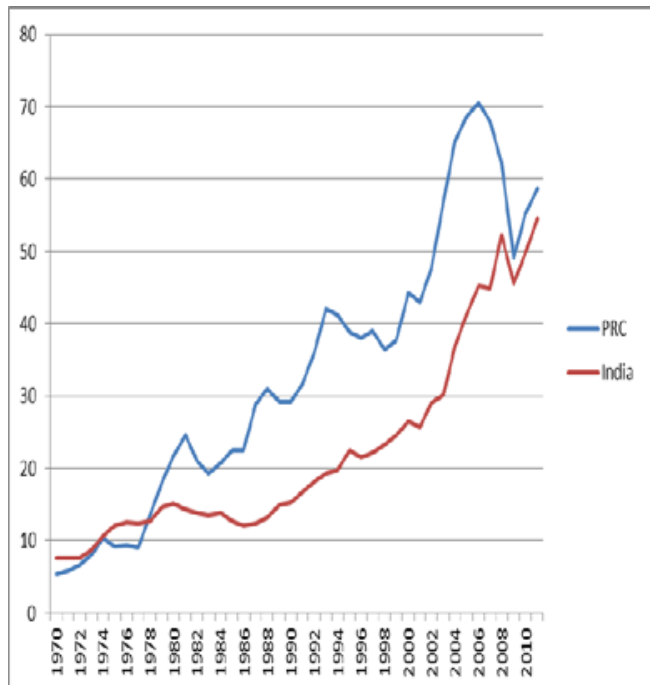

Source: World Development Indicators (2012)

\section{Export \% of GDP}

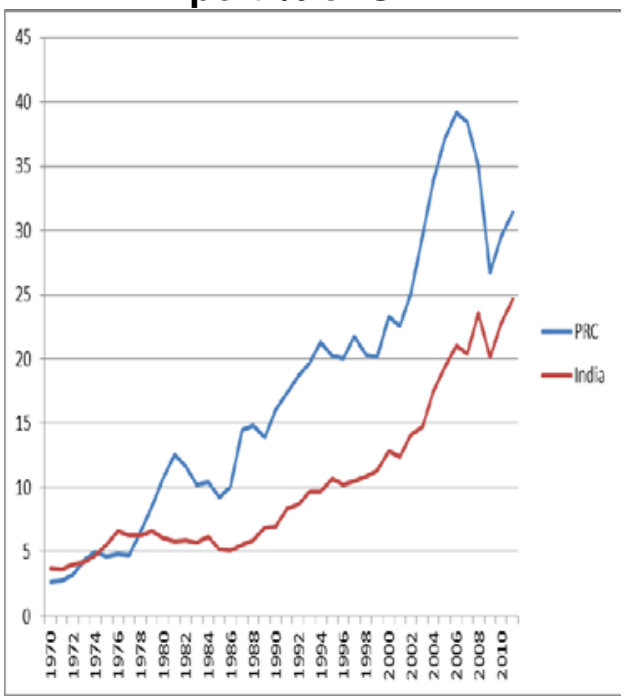

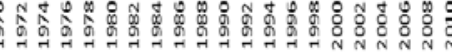

Despite the increase, the trade sector of India is still smaller in comparison with the PRC. Moreover, sectoral analysis of trade shows that in contrast to India, the PRC focused on the trade of manufactured goods. This may be attributed to the integration of PRC with East Asian production networks. The ratios of exports and imports of manufactured goods to respective total merchandise exports and imports have been increasing rapidly in the PRC (Figures 14 and 15). Particularly, the manufacturing exports of PRC almost doubled from 48 percent in 1984 to 94 percent in 2010. The same is the case for India, albeit not as significant as PRC, as the share of manufacturing exports to the total Indian exports also increased from 59 percent in 1980 to 64 percent in 2010 (Figure 13). In terms of composition, bulk of the PRC's manufactured exports used to be miscellaneous manufactures, which encompasses most of the traditional labor-intensive products. However, after 2000, there has been a noticeable shift to more sophisticated goods in machinery product lines as the share of machinery and transport equipment increased from less than 40 percent to more than 50 percent from 2005 to 2010. In contrast, the manufactured exports of India continued to be composed mainly of resource-based products (e.g., primary and fabricated metals). Nevertheless, there was also a modification in the composition of Indian manufactured exports as the share of machinery and transport equipment substantially improved from less than 10 percent to more than one-fifth, replacing the labor-intensive miscellaneous manufactures as the second major manufactured export product of India (Table 18). 
Meanwhile, the share of fuel export to total merchandise exports of PRC has been decreasing since the 1980s. From its peak at 26 percent in 1985, it dropped to 2 percent in 2010, reflecting the rising domestic demand for energy. In early 1980s, the share of fuel export to total merchandise exports of India spiked at 16 percent in 1983. While this ratio declined during 1990s, it revived in recent years, even reaching 17 percent in 2010. From 1984 and 2010, the ratio of food exports to total merchandise exports has been decreasing gradually for each country-from 15 percent to 3 percent for PRC and from 23 percent to 8 percent for India, respectively.

Figure 13. Export Composition of PRC and India (\% of merchandise exports), 1962-2010

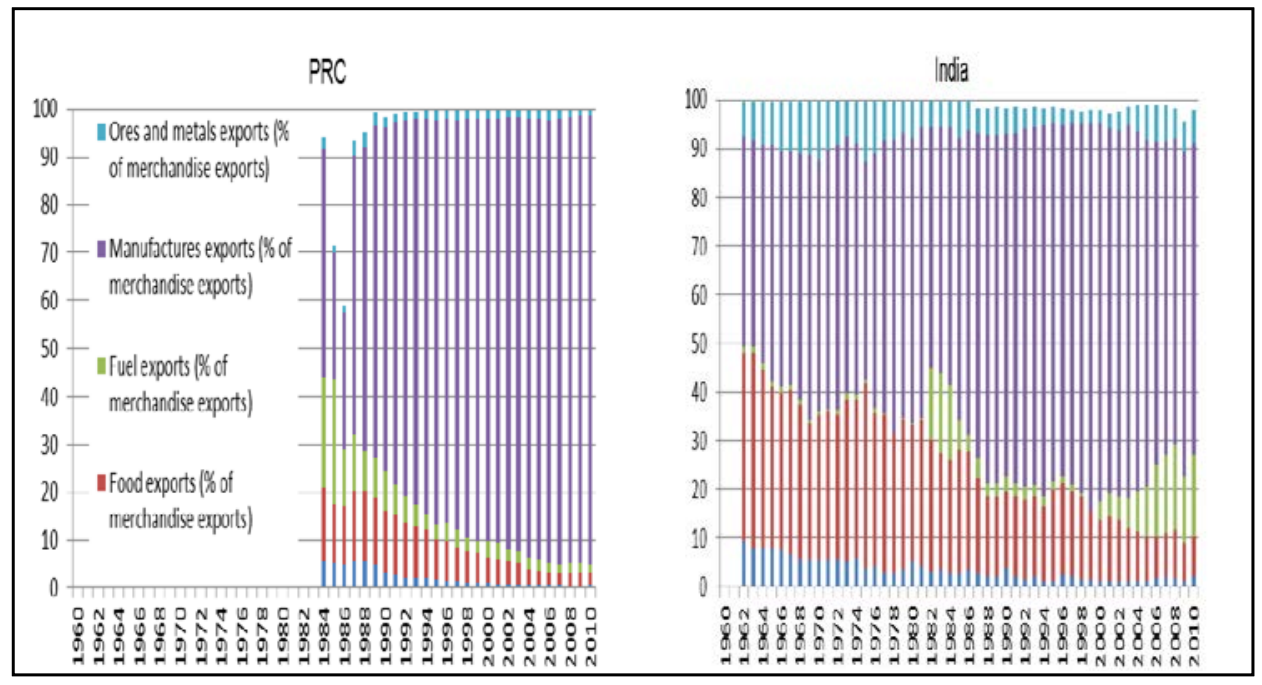

Source: World Development Indicators (2012)

Table 18. Distribution of manufacturing exports, by PRC and India (in \%), 2000-2010

\begin{tabular}{|c|c|c|c|c|c|c|c|c|c|c|c|}
\hline \multirow{2}{*}{$\begin{array}{l}\text { SITC } \\
\text { Rev.3 }\end{array}$} & & \multicolumn{5}{|c|}{ China } & \multicolumn{5}{|c|}{ India } \\
\hline & & 2000 & 2005 & 2008 & 2009 & 2010 & 2000 & 2005 & 2008 & 2009 & 2010 \\
\hline 5 & Chemicals & 5.5 & 5.1 & 6.0 & 5.5 & 5.9 & 13.2 & 16.1 & 18.1 & 15.8 & 17.1 \\
\hline $\begin{array}{c}6 \\
\text { Minus } 68\end{array}$ & $\begin{array}{c}\text { Resource- } \\
\text { based products }\end{array}$ & 17.8 & 16.9 & 18.2 & 15.4 & 15.7 & 50.3 & 45.2 & 40.9 & 34.0 & 40.1 \\
\hline 7 & $\begin{array}{l}\text { Machinery and } \\
\text { transport } \\
\text { equipments }\end{array}$ & 37.6 & 50.3 & 50.6 & 52.6 & 52.9 & 9.4 & 14.9 & 21.8 & 23.0 & 23.1 \\
\hline 8 & $\begin{array}{l}\text { Miscellaneous } \\
\text { manufacturing } \\
\text { articles }\end{array}$ & 39.1 & 27.7 & 25.2 & 26.6 & 25.5 & 27.1 & 23.7 & 19.3 & 27.2 & 19.7 \\
\hline & $\begin{array}{l}\text { All } \\
\text { manufacturing } \\
\text { products }\end{array}$ & 100.0 & 100.0 & 100.0 & 100.0 & 100.0 & 100.0 & 100.0 & 100.0 & 100.0 & 100.0 \\
\hline & $\begin{array}{l}\text { Shares of } \\
\text { manufacturing } \\
\text { sector in total } \\
\text { exports }\end{array}$ & 78.7 & 83.8 & 84.4 & 84.6 & 84.5 & 56.4 & 46.7 & 37.9 & 46.0 & 42.4 \\
\hline
\end{tabular}

Source: Anukoonwattaka (2011)

In terms of import composition, while the share of manufacturing import to total imports has been decreasing from 1984 to 2010 for PRC (from 69\% to 61\%), manufactured import still accounts for the bulk of total imports of the country. For India, the share of manufactured goods still increased (from $49 \%$ to $51 \%$ ) and it maintained a major share in India's total imports (Figure 14). In terms of composition, manufactured imports of both countries are mainly comprised of machinery and transport equipment. For PRC, the second dominant imported 
manufacture was chemicals, which replaced resource-based products. For India, resource-based products remained as the second major manufactured import, followed by chemicals (Table 19).

As pointed out by Anukoonwattaka (2011), the consistent dominance of machinery and transport equipment in the manufactured exports and imports of PRC indicates the two-way trading of this good in the manufacture trade of the said country. This is currently not the case in the manufacture trade of India as the country imports mostly machinery and transport equipment but exports mainly resource-based products. According to Anukoonwattaka (2011) this trade pattern of manufacturing goods of India reflects the import substitution policy of India in early 1990s, which put emphasis on large-scale, capital-intensive industries.

Figure 14. Import Composition of PRC and India (\% of merchandise imports), 1962-2010

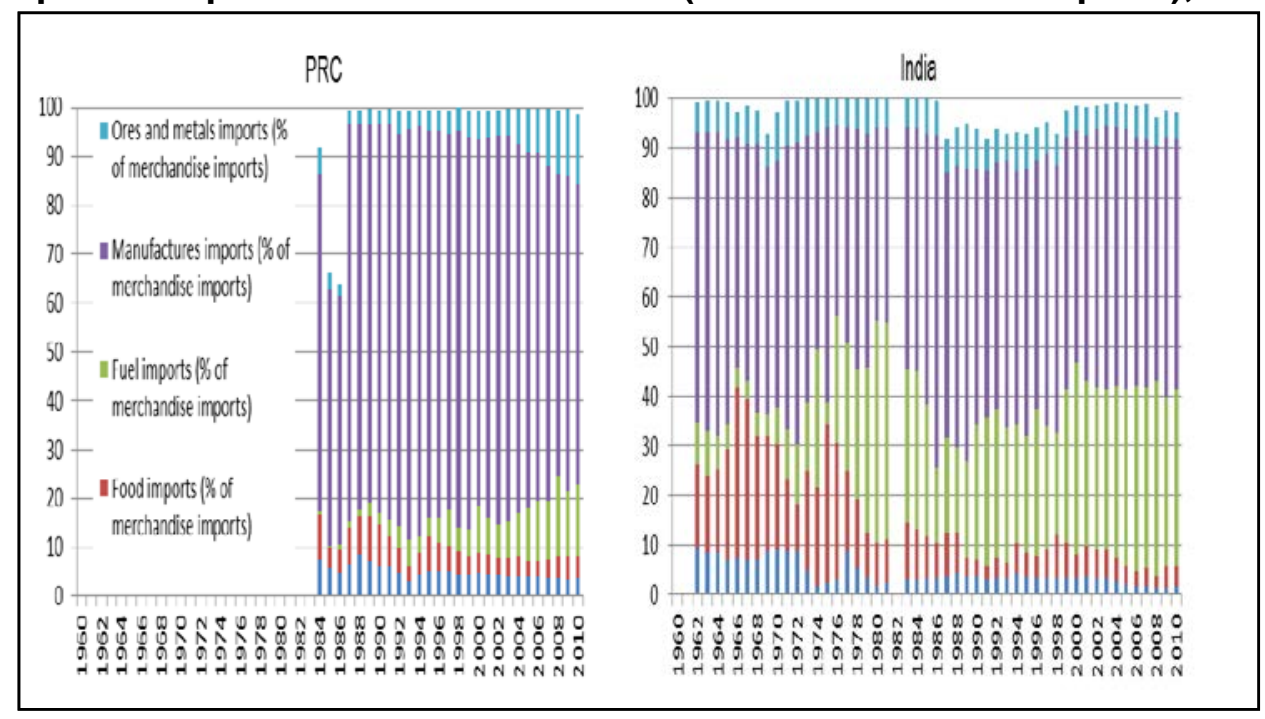

Source: World Development Indicators (2012)

Table 19. Distribution of manufacturing imports, by PRC and India (in \%), 2000-2010

\begin{tabular}{|c|c|c|c|c|c|c|c|c|c|c|c|}
\hline \multirow{2}{*}{$\begin{array}{l}\text { SITC } \\
\text { Rev.3 }\end{array}$} & & \multicolumn{5}{|c|}{ China } & \multicolumn{5}{|c|}{ India } \\
\hline & & 2000 & 2005 & 2008 & 2009 & 2010 & 2000 & 2005 & 2008 & 2009 & 2010 \\
\hline 5 & Chemicals & 18.3 & 17.4 & 18.1 & 18.6 & 18.6 & 20.8 & 20.2 & 24.7 & 21.4 & 22.4 \\
\hline $6-68$ & $\begin{array}{l}\text { Resource- } \\
\text { based products }\end{array}$ & 20.5 & 13.6 & 10.9 & 11.1 & 9.7 & 35.7 & 30.1 & 23.2 & 25.2 & 31.1 \\
\hline 7 & $\begin{array}{l}\text { Machinery and } \\
\text { transport } \\
\text { equipment }\end{array}$ & 53.7 & 57.0 & 58.1 & 57.8 & 59.1 & 34.7 & 42.0 & 46.4 & 45.7 & 40.0 \\
\hline 8 & $\begin{array}{l}\text { Miscellaneous } \\
\text { manufacturing } \\
\text { articles }\end{array}$ & 7.5 & 12.1 & 12.8 & 12.4 & 12.6 & 8.8 & 7.7 & 5.7 & 7.7 & 6.6 \\
\hline & $\begin{array}{l}\text { All } \\
\text { manufacturing } \\
\text { products }\end{array}$ & 100.0 & 100.0 & 100.0 & 100.0 & 100.0 & 100.0 & 100.0 & 100.0 & 100.0 & 100.0 \\
\hline & $\begin{array}{l}\text { Shares of } \\
\text { manufacturing } \\
\text { sector in total } \\
\text { imports }\end{array}$ & 62.5 & 59.1 & 49.8 & 50.7 & 49.7 & 31.9 & 35.4 & 34.0 & 37.7 & 28.3 \\
\hline
\end{tabular}

Source: Anukoonwattaka (2011)

Meanwhile, due to increased domestic demand for energy, the portions of fuel imports for the PRC and India have been increasing. For India, the share of fuel imports to total imports rose from 32 percent in 1984 to 36 percent in 2010 while for PRC, this went up significantly from 1 percent to 15 percent during the same period. Meanwhile, the imports of ores and metal 
imports have been growing in the PRC (Figure 15).

The trade pattern of PRC reflects the significance of the country as a member of the East Asian production networks. Based on estimates for 2006/2007 of Athukorola (2011) as mentioned in Anukoonwattaka (2011), about half of the trade of parts and components for machinery and transport equipment of the PRC was with Developing East and South East Asian countries, indicating the high production linkage of the PRC with these regions. The share of component in the total manufacturing exports of the country increased more than three times from a two-year average of 7.4 percent in 1992/1993 to 25.6 percent in 2006/2007. In terms of manufacturing imports, the share of component is much higher, growing more than twice from 20.4 percent to 44.0 percent in the same period. These high shares of parts and components in the manufacturing trade of PRC indicate the intensity of production networks in the country (Table 20). Also, the intraregional manufacturing import of PRC was dominated by parts and components (59\%) while the country's intraregional manufacturing export was mainly composed of final goods (59\%) (Figure 15). Breakdown of PRC data on total exports and imports also shows that processed exports remain to be around half of total merchandise exports from 1995 to 2009. In terms of imports, the share of processing was around one third of the total merchandise imports of PRC, although lower than the 44 percent ratio in 1995. Similar trends are observed when compared to total exports and imports of goods and services (Table 21). These indicate that the share of manufactures for final consumption as well as the value added in processed exports remained high for PRC. The trade of PRC is dominated by processing trade.

Table 20: Share of Parts and Components in Manufacturing trade of selected economies, 1992-2007 (two-year average percentage share)

\begin{tabular}{lcc|cc}
\hline Economy & \multicolumn{2}{c|}{ Exports } & \multicolumn{2}{c}{ Imports } \\
\cline { 2 - 5 } & $\mathbf{1 9 9 2 / 1 9 9 3}$ & $\mathbf{2 0 0 6 / 2 0 0 7}$ & $\mathbf{1 9 9 2 / 1 9 9 3}$ & $\mathbf{2 0 0 6 / 2 0 0 7}$ \\
\hline World & 19.3 & 27.1 & 19.6 & 27.3 \\
Developing Asia & 17.3 & 34.0 & 29.0 & 44.2 \\
\hline China & 7.4 & 25.6 & 20.4 & 44.0 \\
Hong Kong, China & 15.8 & 33.3 & 24.1 & 48.5 \\
Republic of Korea & 18.1 & 47.3 & 30.1 & 38.9 \\
Taiwan Province of & 24.7 & 44.2 & 29.5 & 47.9 \\
China & & & & 21.8 \\
ASEAN 6 & 22.7 & 44.2 & 36.0 & 50.0 \\
$\quad$ Indonesia & 3.8 & 21.5 & 27.0 & 61.3 \\
Malaysia & 27.7 & 53.6 & 40.5 & 60.4 \\
Philippines & 32.9 & 71.7 & 32.6 & 36.1 \\
Singapore & 29.0 & 49.3 & 39.9 & 19.1 \\
Thailand & 14.1 & 29.9 & 30.6 & 22.9 \\
Viet Nam & n.a. & 11.0 & n.a. & 17.5 \\
India & 3.0 & 10.4 & & \\
\hline
\end{tabular}

Source: Anukoonwattaka (2011)

Figure 15. Parts and Component vs. Final goods of PRC (\% of manufacturing trade), 2006/2007

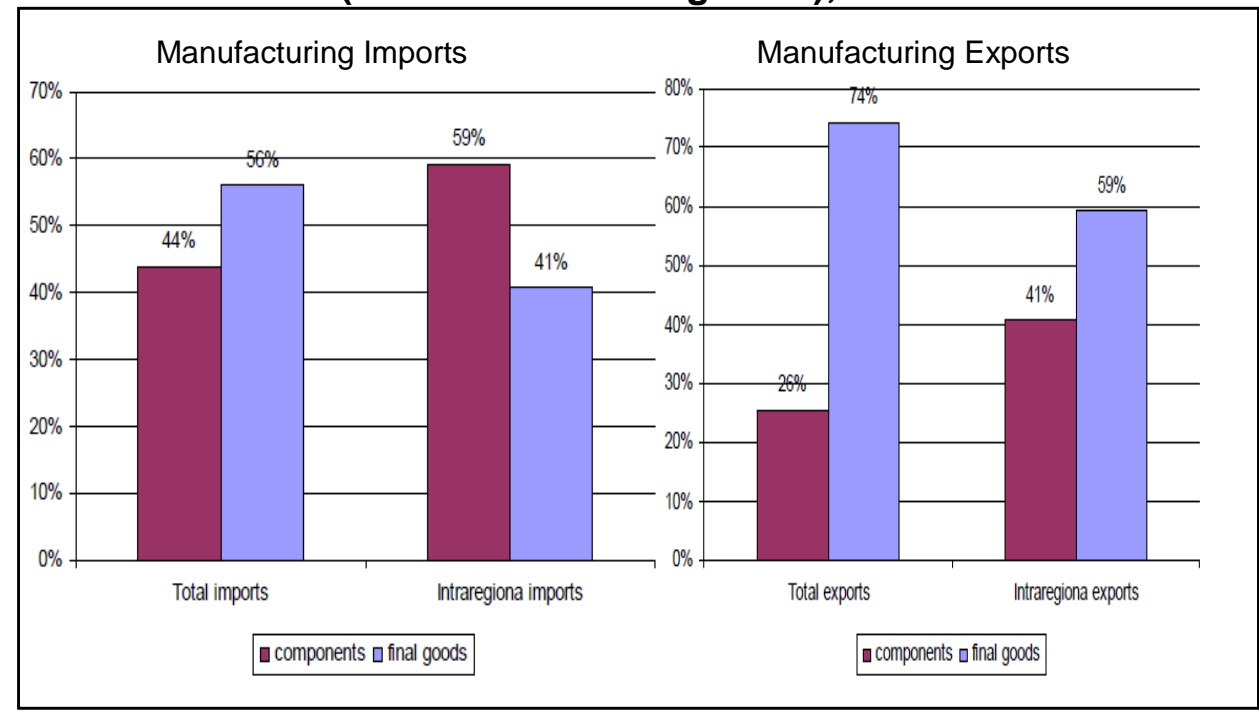

Source: Anukoonwattaka (2011) 
In contrast, processing trade did not contribute much in India's trade. The share of component in manufacturing exports of India is not that significant, although it increased more than three times from 3.0 percent in 1992/1993 to 10.4 percent in 2006/2007. The share of component in manufacturing imports of India rose by 5 percentage points from 17.5 percent to 22.9 percent during the same period (Table 20). These figures reflect that India has not yet participated much in the international production network. This can also be observed in the low shares of parts and components in the manufacturing trade (both exports and imports) of India, in terms of total and intraregional trade (Figure 16), indicating the continued dominance of the traditional form of international trade in finished products in the country.

Table 21: Ratio of Processing Trade in Imports and Exports, PRC, 1995-2009 (\%)

\begin{tabular}{|l|l|l|l|l|}
\hline & $\begin{array}{l}\text { Ratio of } \\
\text { Imports for } \\
\text { Processing } \\
\text { to Imports } \\
\text { of goods } \\
\text { and } \\
\text { services }\end{array}$ & $\begin{array}{l}\text { Ratio of Imports } \\
\text { for Processing } \\
\text { to Total } \\
\text { Merchandise } \\
\text { Imports }\end{array}$ & $\begin{array}{l}\text { Ratio of Exports for } \\
\text { Processing to } \\
\text { Exports of goods } \\
\text { and services }\end{array}$ & $\begin{array}{l}\text { Ratio of Exports } \\
\text { for Processing to } \\
\text { Total Merchandise } \\
\text { Exports }\end{array}$ \\
\hline $\mathbf{1 9 9 5}$ & 43 & 44 & 50 & 50 \\
\hline $\mathbf{2 0 0 0}$ & 37 & 41 & 49 & 55 \\
\hline $\mathbf{2 0 0 5}$ & 38 & 42 & 50 & 55 \\
\hline $\mathbf{2 0 0 9}$ & 29 & 32 & 44 & 49 \\
\hline
\end{tabular}

Source: CEIC (2011), Note: (1) Processed imports are the sum of "processing and assembly" imports and "processing with imported materials" imports. The difference between total imports and processed and ordinary imports is other export. (2) The sum of "processing and assembly" exports and "processing with imported materials" exports. The difference between total exports and processed and ordinary exports is other export.

Figure 16. Parts and Component vs. Final goods of India (\% of manufacturing trade), 2006/2007

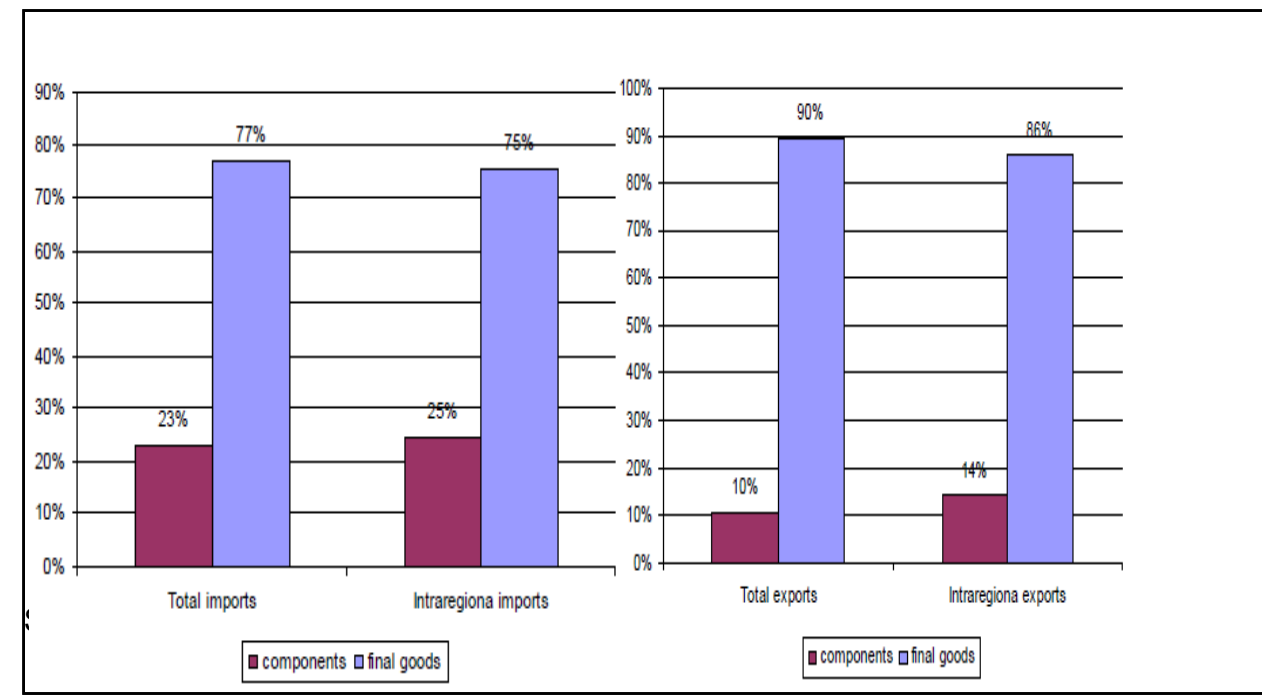

Source: Anukoonwattaka (2011) 
Figure 17. Merchandise and Service Exports, PRC and India, 1980-2010 (current US\$)

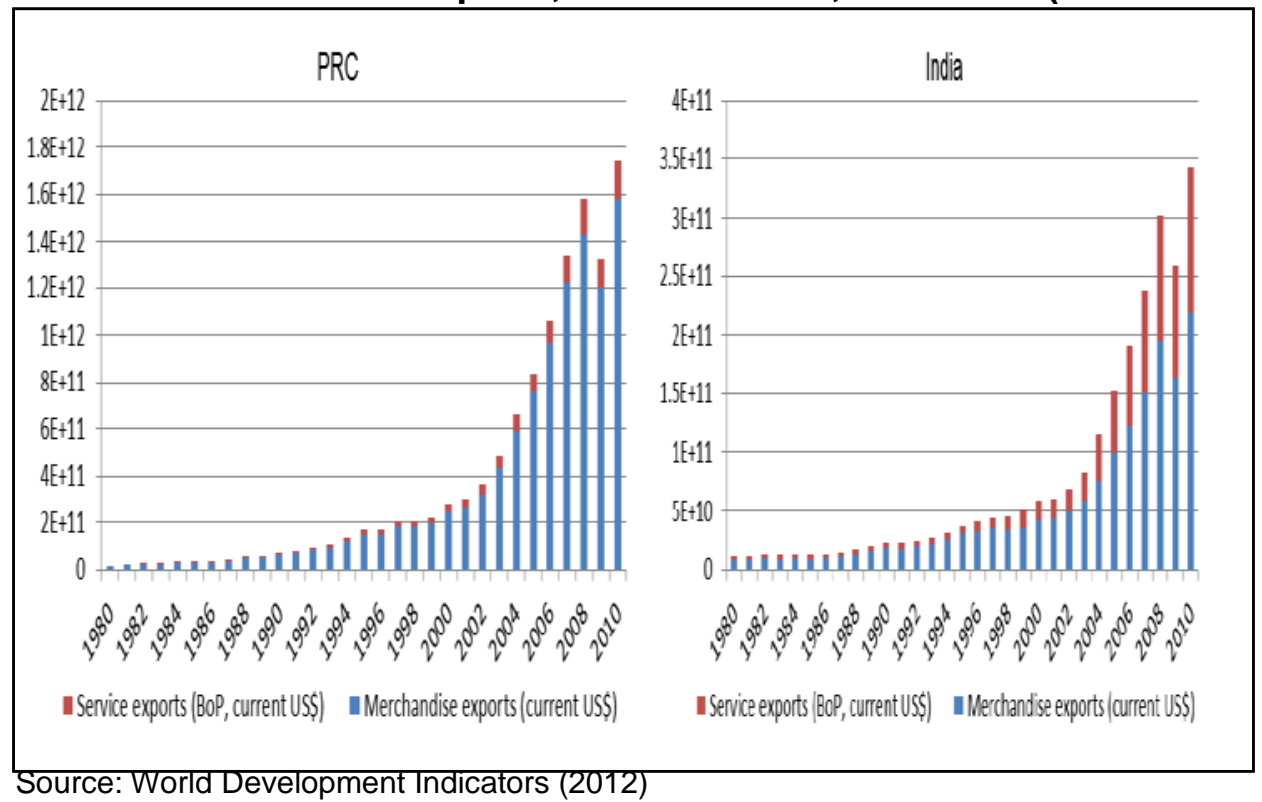

Meanwhile, comparative analysis of merchandise and service exports of the PRC and India from 1980-2010 shows a similar rising trend for both countries, although the scale is much larger for the PRC. However, it is worth noting that the service exports of India comprise a larger share of the total exports of the country compared to that of the PRC (Figure 17).

From US\$2.93 billion in 1982, the service exports of India expanded more than 40 times to US $\$ 123.76$ billion in 2010 while merchandise export reached US\$219.67 billion in 2010, around 23 times greater than the level in 1982 at US\$9.36 billion. For the PRC, service sector exports grew by about 65 times from US $\$ 2.51$ billion in 1982 to US\$162.17 billion in 2010 while goods exports expanded by more than 70 times from US $\$ 22.32$ billion to US\$1,577.82 billion during the same period. The service exports of India increased significantly during the second half of the 2000s. Further, detailed analysis of the composition of service sector exports shows that communications and computer service sector export accounts for a major portion of service exports in India-more than 70 percent in 2010 from 43 percent in 1982. Bulk of this sector is ICT service exports due to the proliferation of Business Process Outsourcing in India, particularly in the fields of financial services, computer software programming, and call centers, among others (Figure 18).

Figure 18. Composition of Service Sector Exports in the PRC and India, 1982-2010 (\% of service exports)

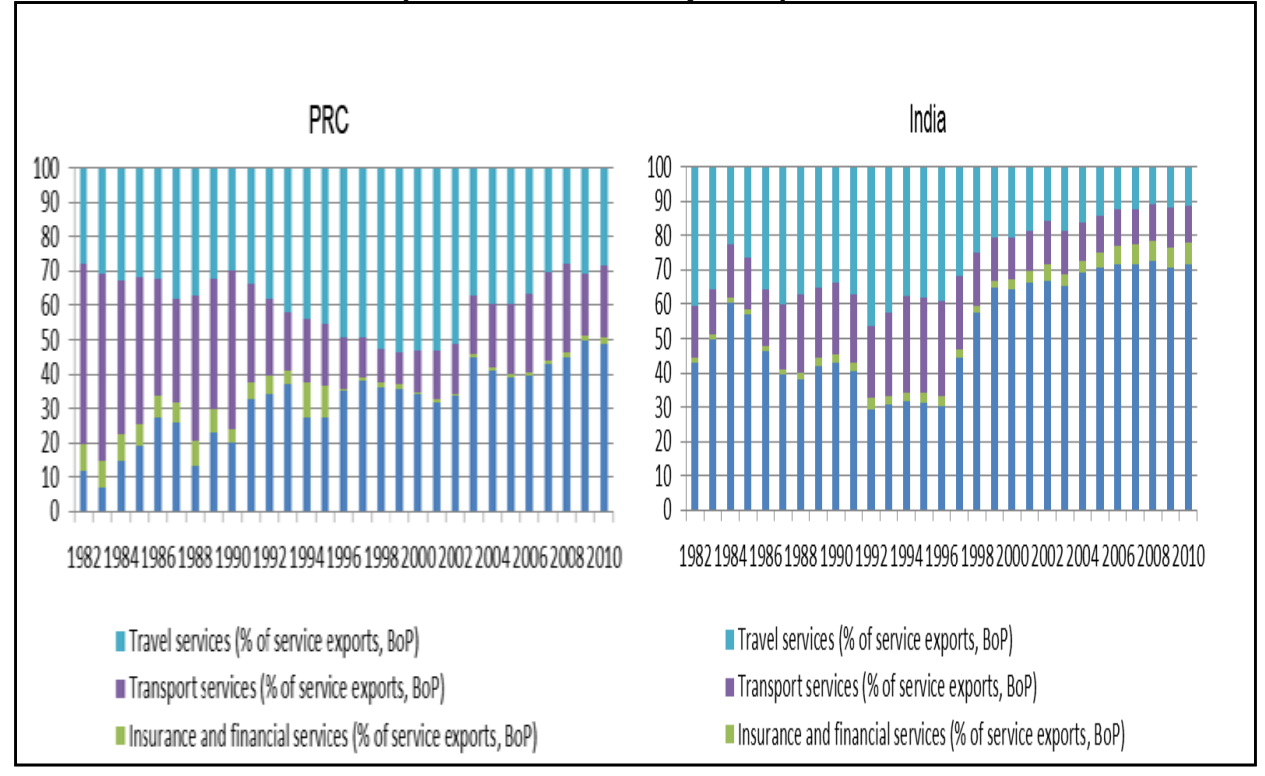

Source: World Development Indicators (2011) 
Meanwhile, communications and computer service sector export is also substantial in PRC followed by export of travel services-the share of ICT exports increased from 12 percent in 1982 to 49 percent in 2010 while travel service exports also increased from 28 percent to 28 percent during the same period (Figure 18).

The trends in Figure 18 also show that the PRC has been rapidly developing its service sector. The share of service sector value added has been increasing from 22 percent to 43 percent from 1980 to 2011 in the PRC (Figure 18). What is notable is that in contrast to other developed Asian economies such as Singapore and Hong Kong, China which are performing strongly in the financial sector, this area is still underdeveloped in India and the PRC as confirmed by the relatively poor share of insurance and financial services export to total service export of both countries in the past decades.

\section{(ii) Comparative Advantage}

Comparative advantages in labor and resource-intensive manufacturing goods have been among major drivers of growth and exports for both the PRC and India. Several studies show that the structures of international specialization have been similar in PRC and India, with comparative advantage in labor and resource intensive manufacturing sectors (e.g. textiles, and clothing). These countries also have comparative advantage in manufacturing sectors that require skill, technology, capital and scale such as organic and inorganic chemicals (Batra and Khan 2005). However, in recent years, the PRC has developed its comparative advantage on both manufactured products and machinery and transport equipment, particularly in processing trade (Rodrik 2008).

The comparative advantage of PRC in producing science-based manufactures is double than that of India (Batra and Khan, 2005). In contrast, India has a comparative advantage in services and software sector, although the country significantly lags behind the PRC in the manufacturing sector (Bhattacharya and Bhattacharyay, 2007). At the disaggregate level, the comparative advantage of India is with the production of materials which are unskilled labor intensive. Within science-based manufactures, India produces medicinal and pharmaceutical products (Rodrik 2008).

Table 22. Relative Comparative Advantage (RCA) Index of the PRC and India

\begin{tabular}{|l|c|c|c|c|}
\hline \multicolumn{1}{|c|}{ Sector } & \multicolumn{2}{c|}{ PRC } & \multicolumn{2}{c|}{ India } \\
\hline & $\mathbf{1 9 9 8}$ & $\mathbf{2 0 0 8}$ & $\mathbf{1 9 9 8}$ & $\mathbf{2 0 0 8}$ \\
\hline Food and Live Animals & 0.61 & 0.38 & $\mathbf{2 . 2 2}$ & $\mathbf{1 . 6 2}$ \\
\hline Beverages and Tobacco & 0.34 & 0.13 & 0.60 & 0.48 \\
\hline Crude Materials & 0.45 & 0.21 & $\mathbf{1 . 7 0}$ & $\mathbf{3 . 0 5}$ \\
\hline Mineral Fuels, Lubricants and Related & 0.28 & 0.09 & 0.06 & 0.02 \\
\hline Animal and Vegetable Oils & 0.14 & 0.07 & $\mathbf{1 . 2 2}$ & $\mathbf{1 . 0 2}$ \\
\hline Chemicals and Related & 0.35 & 0.47 & 0.97 & 1.27 \\
\hline Manufactured Goods & $\mathbf{0 . 8 6}$ & $\mathbf{1 . 2 5}$ & $\mathbf{2 . 5 0}$ & $\mathbf{2 . 4 6}$ \\
\hline Machinery and Transport Equipment & $\mathbf{0 . 7 2}$ & $\mathbf{1 . 3 9}$ & 0.21 & 0.44 \\
\hline Miscellaneous Manufactured Articles & $\mathbf{3 . 4 4}$ & $\mathbf{2 . 8 6}$ & $\mathbf{1 . 5 3}$ & $\mathbf{1 . 4 4}$ \\
\hline Commodities classified elsewhere & 0.20 & 0.10 & 0.28 & 0.32 \\
\hline
\end{tabular}

Source: Yu (2011)

This is supported by an analysis of the relative comparative advantage of PRC and India in 1998-2008 (Yu 2011). Table 22 shows PRC has a comparative advantage in manufactured goods while India has comparative advantage in food and live animals; vegetable and animal oils; and crude materials beside manufactured goods. From 1998 to 2008, the RCAs of PRC increased significantly in miscellaneous manufacturing articles, manufacturing goods; and machinery and transport while the RCA of India for crude materials showed the highest increase. Meanwhile, India's RCAs in food and live animals; beverage and tobacco, crude materials; animals and vegetable oils; and chemicals are higher than those of the PRC (Yu 2011). 
Table 23: Revealed Comparative Advantage and Revealed Import Comparative Advantage, 2000 and 2009

\begin{tabular}{|c|c|c|c|c|}
\hline \multirow[b]{2}{*}{2000} & \multicolumn{2}{|c|}{$\begin{array}{l}\text { Revealed } \\
\text { Comparative } \\
\text { Advantage }\end{array}$} & \multicolumn{2}{|c|}{$\begin{array}{l}\text { Revealed Import } \\
\text { Comparative Advantage }\end{array}$} \\
\hline & PRC & India & PRC & India \\
\hline PRC & 1.0000 & & 1.0000 & \\
\hline India & 0.2581 & 1.0000 & 0.4751 & 1.0000 \\
\hline ASEAN & 0.2591 & 0.3393 & 0.2536 & 0.1941 \\
\hline Japan & 0.1266 & 0.2330 & 0.0264 & 0.0156 \\
\hline $\begin{array}{l}\text { Korea, } \\
\text { Republic } \\
\text { of }\end{array}$ & 0.2721 & 0.3052 & 0.3077 & 0.2785 \\
\hline US & -0.0998 & -0.0152 & -0.1044 & -0.0834 \\
\hline EU & -0.1383 & -0.1497 & -0.1948 & -0.0871 \\
\hline $\begin{array}{l}\text { Russian } \\
\text { Federati } \\
\text { on }\end{array}$ & -0.2532 & -0.1106 & -0.0956 & -0.0218 \\
\hline 2009 & PRC & India & PRC & India \\
\hline PRC & 1.0000 & & 1.0000 & \\
\hline India & 0.3023 & 1.0000 & 0.7106 & 1.0000 \\
\hline ASEAN & 0.3766 & 0.3325 & 0.2925 & 0.2321 \\
\hline Japan & 0.5601 & 0.2737 & 0.0863 & 0.0258 \\
\hline $\begin{array}{l}\text { Korea, } \\
\text { Republic } \\
\text { of }\end{array}$ & 0.5976 & 0.2940 & 0.3542 & 0.3653 \\
\hline US & 0.0014 & 0.2872 & -0.0846 & 0.0723 \\
\hline $\begin{array}{l}\text { EU } \\
\text { Russian }\end{array}$ & 0.0754 & -0.2788 & -0.5183 & -0.5223 \\
\hline $\begin{array}{l}\text { Federati } \\
\text { on }\end{array}$ & -0.1514 & -0.0970 & 0.0187 & -0.0765 \\
\hline
\end{tabular}

- = negative, ASEAN = Association of Southeast Asian Nations, PRC = People's Republic of China, EU = European Union, US = United States.

Source: CEPII. CHELEM 2011. http://www.cepii.fr/anglaisgraph/bdd/chelem.htm

Based on revealed comparative advantage estimates, the development patterns of trade of the PRC and India are not identical (Table 23). The PRC has competing relations with India, ASEAN counties, Japan, and the Republic of Korea (Korea henceforth) and in 2009, this competing relations intensified. The trade relation of the country with the US and EU changed from being complementary in 2000 into slightly competing in 2009, but it kept a complementary relation with Russia. Meanwhile, India also has competing relations with the PRC, ASEAN, Japan and the Republic of Korea, all of which intensified in 2009 except for Korea. India continued to have a complementary trade relation with the $\mathrm{EU}$, but its trade relation with the US changed from complementary in 2000 into competing in 2009. Meanwhile, similar with the PRC, India has a complementary relation with Russia.

For imports, PRC also has competing relations with India, ASEAN, and Korea, which intensified in 2009, particularly that with India. The country's relation with Japan used to be close to neutral in 2000 but this became slightly competing nine years after. The complementary import relation of the PRC with the US remained the same while that with the EU intensified. With Russia, import relation of the PRC changed from being complementary in 2000 into competing in 2009. In the case of India, competing relations of the country with the PRC, ASEAN and Korea increased from 2000 to 2009 and as indicated above, the competing relation between the PRC and India considerably intensified. The import relation of India with Japan also remained closer to neutral but with the US, 
it shifted from being complementary into competing. Meanwhile, the complementary relation of India with EU and Russia considerably increased.

\section{(iii) Foreign Direct Investment}

FDI is one of the major drivers for rapid growth for the PRC and India. FDI inflows began to increase notably in the PRC in the early 1990s and India in the mid-2000s. FDI stock in the PRC increased remarkably from US\$ 1 billion in 1980 to US\$578 trillion in 2010. Similarly, albeit at a lower scale, India's FDI stock increased from US\$ 471 million to US\$ 197 trillion within the same period. The ratio of FDI to GDP of the PRC has been consistently higher than that of India up until 2008 (Figure 19).

The proximity of the PRC with the production network bases of East Asia such as Japan, Korea and Taipei,China along with the determination of the government of the PRC to encourage the inflow of foreign investments through rapid and quality infrastructure development and various incentive policies have attracted many foreign companies to relocate their factories in the PRC (Gill and Kharas 2007). Thus, the growth of the PRC was enhanced by huge FDI inflow, which supported the development of infrastructure and manufacturing sectors as well as helped in sustaining the growth and development of the country for a long period of time.

Figure 19. Foreign Direct Investment Inflows to PRC and India, 1980-2010

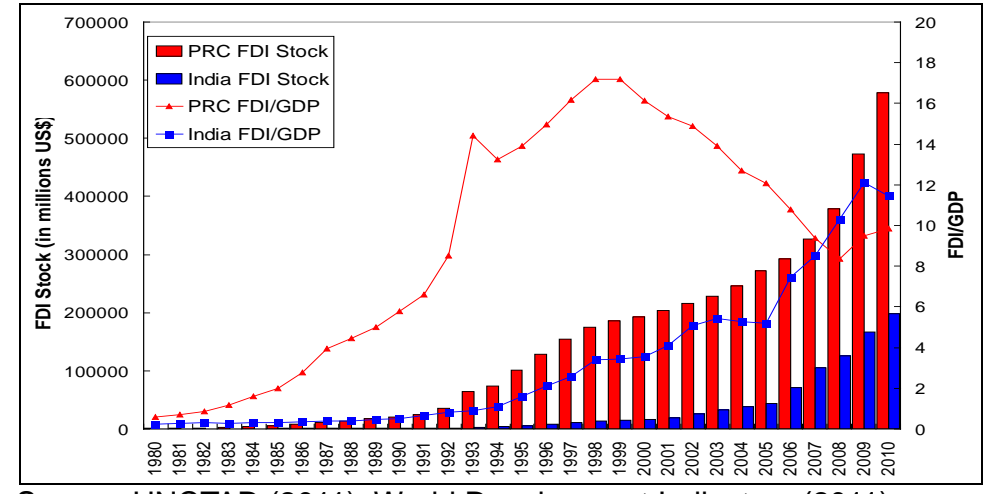

Source: UNCTAD (2011), World Development Indicators (2011)

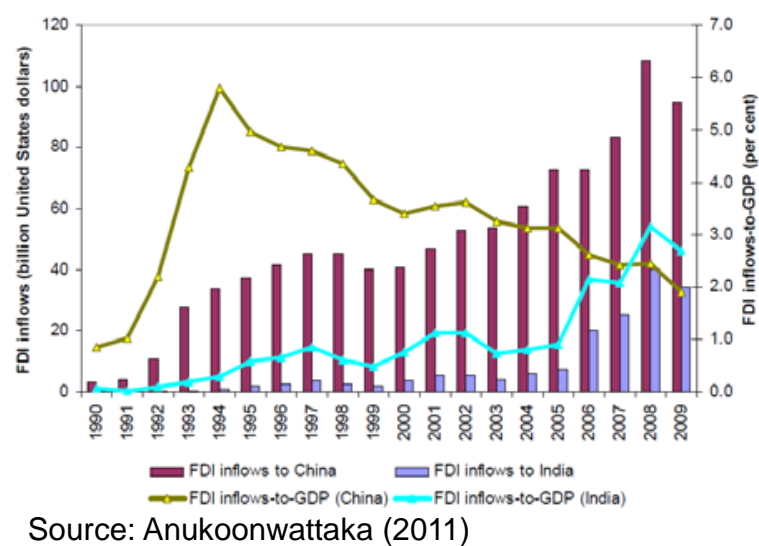

In contrast to the PRC, India reduced its public investment in light of the 1991 balance of payment crisis and instead pursued policies to increase private investment (Singh 1993). These caused shortage of fund for development activities and particularly resulted in insufficient and ineffective infrastructure development in the country. This infrastructure bottleneck functioned as a hindrance in attracting FDI and in the development of the manufacturing sector for India. Moreover, geographically, India is located relatively distant from regional and global production network bases in Asia. It also has relatively less open investment policies. All these factors functioned as underlying cause for attracting less FDI stock and FDI per capita in India as compared to PRC (Gerhaeusser 2010). 
Figure 20. Foreign Direct Investment Inflows to PRC and India by Sector, 2005-2008
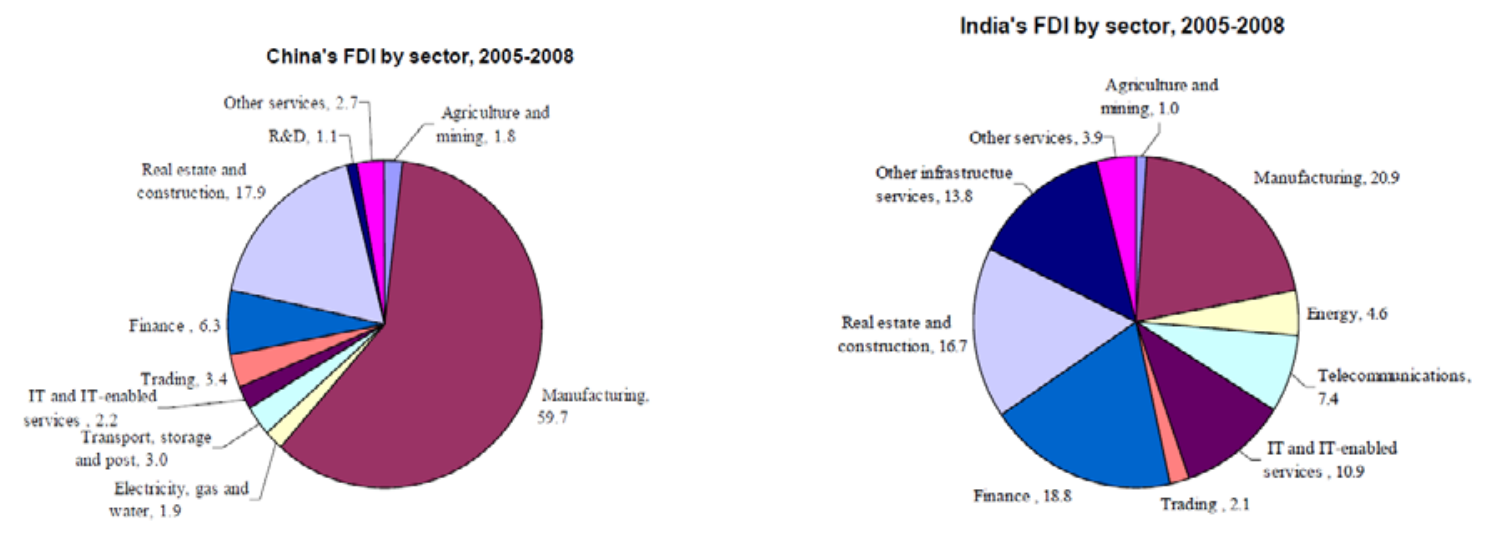

Source: Anukoonwattaka (2011)

However, recently starting in 2008, the ratio of FDI stock to GDP of India surpassed that of PRC, increasing to 11.45 percent in 2010 from 5.18 percent in 2005. The FDI-to-GDP ratio of PRC decreased from 12.05 percent in 2005 to 9.84 percent in 2010.

Table 24. Foreign Direct Investment, per Sector for PRC, $\mathbf{2 0 0 0 - 2 0 1 1 ^ { 5 }}$

\begin{tabular}{|l|r|}
\hline \multicolumn{1}{|c|}{ Sector } & US\$ (million) \\
\hline Manufacturing & $\mathbf{4 4 3 , 1 5 6}$ \\
\hline Real Estate & 116,751 \\
\hline Banking \& Insurance & 50,419 \\
\hline Transport, Storage \& Postal Service & 18,401 \\
\hline Electricity, Gas \& Water Production \& Supply & 18,003 \\
\hline Agriculture & 11,491 \\
\hline Construction & 8,662 \\
\hline Mining & 5,912 \\
\hline & $\mathbf{2 0 0 4 - 2 0 1 1}$ \\
\hline Leasing and Commercial Service & $33,077.9$ \\
\hline Wholesale and Retail Trade & $22,662.49$ \\
\hline Information Transmission, Computer Service \& Software & $11,994.76$ \\
\hline Scientific Research, Polytechnic Service \& Geological & $7,201.16$ \\
\hline Accommodation \& Catering Trade & $5,987.97$ \\
\hline
\end{tabular}

Notes: Sum of Flows for The PRC

Sources: CEIC (2011)

Furthermore, consistent with their economic structure and trade composition, FDI inflows to the PRC is generally directed toward the manufacturing sector while for India, it is toward the service sector (Figure 21 and Tables 24 and 25). From 2005 to 2008, both the manufacturing sector in the PRC and the services sector (i.e., finance, real estate and construction, IT and IT-enabled services, telecommunications) in India accounted for around 60 percent of the total FDI (Figure 20). For the period 2000-2011, manufacturing sector in PRC received majority of the FDI amounting to US\$ 443 billion. The PRC also attracted large investment in nontradeable sectors like real estate and utilities. For India, the service sector shared the largest part of FDI amounting to US\$28 billion, with computer hardware and software; telecommunications; and real estate and construction sector as major recipients (Table 25).

\footnotetext{
${ }^{5}$ For some major sectors, data is only available from 2004 in PRC. Sectoral definitions in India and The PRC may be different.
} 
Table 25. Foreign Direct Investment, per Sector for India, April 2000-April 2011

\begin{tabular}{|l|r|}
\hline \multicolumn{1}{|c|}{ Sector } & US\$ (million) \\
\hline $\begin{array}{l}\text { Service Sector } \\
\text { (financial \& non-financial) }\end{array}$ & 27,668 \\
\hline Computer Software and Hardware & 10,821 \\
\hline Telecommunications & 10,611 \\
\hline Housing and Real Estate & 9,655 \\
\hline Construction Activities (including roads \& highways) & 9,491 \\
\hline Automobile Industry & 6,199 \\
\hline Power & 6,156 \\
\hline Metallurgical Industries & 4,286 \\
\hline Petroleum and Natural Gas & 3,159 \\
\hline Chemicals (other than fertilizers) & 2,927 \\
\hline
\end{tabular}

Sources: Department of Industrial Policy \& Promotion Ministry of Commerce and Industry (2011)

\section{Models of Growth and Development}

\subsection{Overall policy reforms and institution building}

In the 1950s, both the PRC and India followed similar kind of inward-oriented, state-controlled economic strategies. In the case of the PRC, economic reform got real momentum after 1978 when it began to open up its market to foreign investment. At the same time, the Cultural Revolution along with the ideological shift in the Chinese communist party led the way to market-oriented reforms in the PRC (Bajpai and Jian 1996). Thus, PRC has followed export-oriented growth model and welcomed private capital and relied more on large-scale enterprises for its economic growth.

In the late 1970s to the early 1980s, the PRC opened up its economy to foreign investment. While local entrepreneurs and foreign investors to a certain extent were given permission to start up business, most industries still remained state-owned. Enhanced deregulation and privatization began in the early 1980s for the PRC when it began to transfer management and then ownership of state-owned enterprises to private hands (Wignaraja 2011). However, the turning point was when the PRC joined WTO in 2001 (OECD 2005). The PRC reduced tariffs, trade barriers and regulations in accordance with its membership. It took a step further by not only opening access to investment and lowering tariff for trade, but also provided incentive for foreigners to establish businesses in the PRC.

Meanwhile, reforms in India began much later than the PRC at the advent of the balance of payments crisis in 1991. In the 1980s, India began to liberalize its economy by allowing the importation of raw materials and machinery that were not produced domestically. In the mid-1980s however, this "did not represent a break from the inward-oriented approach" (Chandra and Kumar 2008). Therefore, India still remained to be essentially closed to international trade because of their prohibitively high import tariff rates and export taxes. Nevertheless, other similar fundamental reforms were put in place which paved the way for reforms in the 1990s.

Thus, India began major opening of its economy almost a decade later than the PRC in 1991 when it removed its business licensing regime. India also put in place appropriate trade and investment policies, particularly for attracting capital inflows and for tariff liberalization. During this time, reforms were done through elimination of duties on imports of information technology products, relaxation of controls on both inward and outward investments and foreign exchange (Gullapalli 2005). India's economic opening and liberalization policies got further momentum when it joined the WTO in 1995 (Guruswamy et. Al. 2009). 
However, there are some debates about the significance of reforms in India after the balance of payment crisis of 1991. De Long (2001) and Rodrik (2002) argued that reforms undertaken in the 1990s were not significant, because economic growth began in the 1980 s even before the post 1991 crisis reforms. Panagariya (2004) argued however that growth in the 1980s was highly unstable and it even culminated in the balance of payment crisis in 1991 as growth at that time was driven by unsustainable borrowing, among others. Nevertheless, he credited "liberalization by stealth" which began in the 1970s and took hold in the 1980s.

Thus, both countries took a step beyond liberalization by taking various steps for institution building and financial sector development. The PRC provided fiscal incentives and established Special Economic Zones (SEZs), among others. Similarly, the Indian government supported the IT sector through fiscal incentives, establishment of Export Oriented Units (EOU), Software Technology Parks (STP), and Special Economic Zones (SEZ).

\section{Institution building}

Institutional reforms in India and the PRC were supported by central steering agencies like the PRC's National Development and Reform Commission (NDRC) and India's Planning Commission. Particularly, for effective planning and implementation of economic and policy reforms in the PRC, the NDRC has played a vital role. Particularly, in planning and implementing policies and projects related to infrastructure development in PRC, NDRC played significant role. NDRC combines top-down guidance with troubleshooting, coordination, and clearing-house functions, which has greatly enhanced execution capacity of institution in PRC (Gerhaeusser, eds. et. al. 2010).

Further, decentralization of institutions also played an important role in developing economic centers in the PRC. Provinces were given both a larger role as well as incentives for their economic development. Competition among local governments was commonplace. Furthermore, decentralization of local revenues and expenditures stimulated incentives for economic efficiency (Bajpai and Jian 1996).

In contrast, although the Indian government was able to implement political decentralization, local governments did not have economic power to initiate changes (Singh 2007). Indian political Institutions with a democratic pluralistic system could be an asset for balanced and sustainable development. India's democratic political pluralism where different constituents make their claims has kept the economic policies balanced and moderate. The PRC does not have the moderating impact of competing and dissenting voices in design and execution of public policies. However, due to centralized decision making system in the PRC it can approve any policies faster. In contrast, the democratic system in India entails necessary approvals from a parliament or congress which usually takes longer time (Guruswamy, et. Al. 2009). Furthermore, the Federal type of government in India along with strong decentralization and power at the provincial level causes slow decision making for reforms and policy implementation (Leger, no date). In comparing impact of political system's on growth and development of both countries Bardhan (2010) states, "Authoritarianism policy of the PRC has distorted the PRC's development while democratic governance in India has been marred by severe accountability failures". Therefore, in terms impact on economic growth and development, institutions has both positive and negative role for both PRC and India.

\subsection{Trade and Investment Policy Reforms and Investment Climate}

India and PRC have been active forging Free Trade Agreements with several Asian countries and with ASEAN as a whole (Bhattacharyay, 2006). Apart from FTA policies and the opening up of markets, the PRC and India also enacted several reforms to boost trade and investment.

\section{Trade reforms}

For trade, the PRC promoted export growth of domestic enterprises by liberalizing export licensing and quotas in 1991. A new custom regulation rationalizing the tariff schedule passed 
in 1985. Further tariff cuts were put in place in 1991 as part of its accession to WTO. Moreover, The PRC supported the trade sector through monetary policy aimed at reforming the foreign and domestic currency exchange system starting with the unification of dual exchange rates in 1994, devaluation of the domestic currency and domestic currency convertibility on current account transaction in 1997 (Wignaraja 2011).

India began its reforms later in 1991 when India introduced policy reform for reducing import tariffs particularly on nonagricultural products. It also abolished the policy of import licensing on machinery and raw materials in the same year and on consumer goods in 2001. In 1995, India joined in WTO as a founding member further liberalizing its import policies. Similar to the PRC, monetary reforms were also undertaken such as the commencement of current account convertibility in 1994 and maintenance of a depreciated exchange rate from 2000 onwards (Wignaraja 2011).

\section{Investment reforms}

Starting in the 1970s, the PRC liberalized its monopoly state trading. Then, an export-processing law was passed to provide incentives for the processing and assembly of imported inputs in 1979. However, by this time, PRC has not fully liberalized yet as it adopted a dualistic trade regime to promote exports via FDI and controlled liberalization of protected domestic sectors. Nevertheless, export-oriented FDI and foreign-owned enterprises were attracted by a series of laws, notably the Sino-Foreign Equity Joint Venture Law of 1979, Sino-Foreign Cooperative Joint Venture Law of 1986, and the Wholly Foreign-Owned Enterprise Law of 1988. The PRC also created special economic zones with facilities like good infrastructure, tax incentives, duty free access to imported raw materials and adopted more liberal labor regulations. Other policies that promoted investment include active policies to facilitate technology upgrading and domestic technological development and heavy investments in R\& D, scientists, and engineers to absorb imported technologies (Wignaraja 2011).

Fom 1991 onwards, India promoted investment by liberalizing restrictions on foreign ownership and the opening up of previous restricted sectors like mining, software, telecommunications for foreign investment. In 1996, restrictions on foreign ownership liberalized further by adopting a formal FDI policy. A Special Economic Zones Act by giving various fiscal and financial incentives was passed to promote exports from both foreign and local enterprises in 2005. India's FDI flows have increasingly shifted toward services, particularly ICT services and financial services. Still many areas of Indian economic activity remain closed to FDI including nuclear, foreign airlines, much of agriculture, and parts of small-scale industry (Wignaraja 2011).

\section{Business climate}

In spite of positive policy reforms described above, that PRC and India are still a long way to go in improving their overall business environment which is crucial for sustaining FDI flows and technology transfer (Table 31). Compared with developed countries of the Asian region as well as developed and emerging economies of other regions, they still have stumbling blocks, particularly in property rights, receiving business permits and taxation. The Ease of Doing Business Chart below shows that in 2010 India (135) and PRC (78) was ranked far behind compare to Korea, Rep. (15) and Japan (19). Even India's position is much lower than emerging economies like Brazil and Russian Federation.

Despite above policy reforms, there is a mixed outcome in PRC and India in terms of their infrastructure quality and global competitiveness index (GCl) in recent years (Table 32). For instance, both the competitiveness and infrastructure quality has improved. As for $\mathrm{GCl}$ ranking, it moved from 47 in 2001-2002 to 27 in 2010-2011 and for infrastructure, it improved from 61 position to 50 position during the same period. At the same time, PRC's infrastructure score also improved from 2.9 in 2001-2002 to 4.44 in 2010-2011. 


\section{Infrastructure Quality}

Infrastructure development is one of the main drivers of competiveness. India's global competitiveness and infrastructure quality both declined as for $\mathrm{GCl}$ it moved from the $36^{\text {th }}$ position in 2001-2002 to $51^{\text {th }}$ position in 2010-2011. For infrastructure quality, its rank changed from the 66 position in 2001-2002 to 86 in 2010-2011. However, though in global comparison India's quality reduced, it's over all infrastructure quality has improved as its score increased from 2.6 to 3.49 during this period. The PRC has witnessed significant improvement in $\mathrm{GCl}(27$ in 2010-2011 from 47 in 2001-2002) and also in infrastructure quality (50 in 2010-2011 from 61 in 2001-2002).

Table 31. Ranking and Score of Global Competitiveness Index (GCI) and Infrastructure Quality Assessment

\begin{tabular}{|c|c|c|c|c|c|c|c|c|c|c|c|c|c|c|c|}
\hline & \multicolumn{3}{|c|}{ 2001-2002 } & \multicolumn{4}{|c|}{$2008-2009$} & \multicolumn{4}{|c|}{$2009-2010$} & \multicolumn{4}{|c|}{$2010-2011$} \\
\hline & \multirow{2}{*}{$\begin{array}{c}\mathbf{G C l} \\
\mathbf{R}\end{array}$} & \multicolumn{2}{|c|}{ Infrastructure } & \multicolumn{2}{|c|}{ GCl } & \multicolumn{2}{|c|}{ Infrastructure } & \multicolumn{2}{|c|}{$\mathbf{G C l}$} & \multicolumn{2}{|c|}{ Infrastructure } & \multicolumn{2}{|c|}{$\mathbf{G C l}$} & \multicolumn{2}{|c|}{ Infrastructure } \\
\hline & & $\mathbf{R}$ & $\mathrm{S}$ & $\mathbf{R}$ & S & $\mathbf{R}$ & $\mathrm{S}$ & $\mathbf{R}$ & $\mathrm{S}$ & $\mathbf{R}$ & $\mathrm{S}$ & $\mathbf{R}$ & $S$ & $\mathbf{R}$ & $\mathrm{s}$ \\
\hline PRC & 47 & 61 & 2.9 & 30 & 4.7 & 47 & 4.2 & 29 & 4.74 & 46 & 4.31 & 27 & 4.84 & 50 & 4.44 \\
\hline India & 36 & 66 & 2.6 & 50 & 4.33 & 72 & 3.4 & 49 & 4.30 & 76 & 3.41 & 51 & 4.33 & 86 & 3.49 \\
\hline
\end{tabular}

Notes:R= Rank; $\mathrm{S}=$ Score

Score: 1-poorly developed, inefficient; 7-among the best in the world

Source: World Economic Forum (2011)

\section{Economic Freedom and Governance}

Institutional reforms and efficiency have played an important role in the rapid development of the PRC and India. This subsection examines the performance of both countries in terms of economic freedom and governance.

In terms of the Index of Economic Freedom, India's position is much better than PRC in some indicators like property rights, investment freedom, labor freedom, while PRC has found better in monetary freedom, business freedom and freedom from corruption The political system of India and the PRC has both positive and negative impacts on policies and governance and thus on growth and development. In 2011, both India and PRC have performed poorly in terms of economic freedom, with overall score 54.6 and 52.0 respectively. Both countries ranked poorly relative to the developed counties like Japan and USA. For some variables, PRC's score is very low compare to India and other emerging countries. For example, for property rights, the PRC's score is only 20 compared to India's 50.0 and Japan and USA's 80.0 and 85.0 respectively. Similarly, for freedom related to business, investment, labor and freedom from corruption both countries score lower compared to the developed countries (Table 33).

Table 33. Index of Economic Freedom 2011

\begin{tabular}{|l|c|c|c|c|}
\hline & PRC & India & $\begin{array}{c}\text { United } \\
\text { States }\end{array}$ & Japan \\
\hline Overall Score & $\mathbf{5 2 . 0}$ & $\mathbf{5 4 . 6}$ & $\mathbf{7 7 . 8}$ & $\mathbf{7 2 . 8}$ \\
\hline World Ranking & $\mathbf{1 3 5}$ & $\mathbf{1 2 4}$ & $\mathbf{9}$ & $\mathbf{2 0}$ \\
\hline Government Spending & $\mathbf{8 7 . 0}$ & $\mathbf{7 7 . 8}$ & 54.6 & 58.7 \\
\hline Monetary Freedom & $\mathbf{7 5 . 3}$ & $\mathbf{6 5 . 1}$ & 77.4 & 87.9 \\
\hline Trade Freedom & $\mathbf{7 1 . 6}$ & $\mathbf{6 4 . 2}$ & 86.4 & 82.6 \\
\hline Business Freedom & $\mathbf{4 9 . 8}$ & $\mathbf{3 6 . 9}$ & 91.0 & 83.8 \\
\hline Freedom from Corruption & $\mathbf{3 6 . 0}$ & $\mathbf{3 4 . 0}$ & 75.0 & 77.0 \\
\hline Fiscal Freedom & $\mathbf{7 0 . 3}$ & $\mathbf{7 5 . 4}$ & 68.3 & 67.0 \\
\hline Labor Freedom & $\mathbf{5 4 . 9}$ & $\mathbf{6 7 . 2}$ & 95.7 & 81.1 \\
\hline Property Rights & $\mathbf{2 0 . 0}$ & $\mathbf{5 0 . 0}$ & 85.0 & 80.0 \\
\hline Financial Freedom & $\mathbf{3 0 . 0}$ & $\mathbf{4 0 . 0}$ & 70.0 & 50.0 \\
\hline Investment Freedom & $\mathbf{2 5 . 0}$ & $\mathbf{3 5 . 0}$ & 75.0 & 60.0 \\
\hline Sourc Heita Fonndaton & & & &
\end{tabular}

Source: Heritage Foundation (2011)

Moreover, the PRC and India consistently rank lower in governance indicators compared to 
other developed Asian economies though India's position has been improving faster than the PRC (Table 34). Data in the table below shows India has evolved fairly robust and indigenous governance institutions and standards (e.g. dispute resolution bodies such as courts, recognition and protection of private and intellectual property rights, a well-developed private sector, and a modestly better score on corruption and rule of law in World Bank's governance indicators) for longer time compared to the PRC. Particularly, the voice and accountability index for India was 60.2 but for the PRC it was only 5.21 in 2009. Similarly for factors like political stability both the PRC and India showed lower index as it changed from around 33 to 30 for the PRC and from around 15 to 13 for India during the 1996 and 2009 respectively.

Table 34. Trends in Governance in PRC and India-1996, 2007 and 2009

\begin{tabular}{|c|c|c|c|c|c|c|c|c|c|c|c|c|c|c|c|}
\hline & \multicolumn{3}{|c|}{ VA } & \multicolumn{3}{|c|}{ PS } & \multicolumn{2}{|c|}{ GE } & \multicolumn{2}{|c|}{ RQ } & \multicolumn{3}{|c|}{ RL } & \multicolumn{2}{|c|}{ CC } \\
\hline & 1996 & 07 & 09 & 1996 & 07 & 09 & 07 & 09 & 07 & 09 & 1996 & 07 & 09 & 07 & 09 \\
\hline PRC & 5.74 & 4.8 & 5.2 & 33.2 & 30.3 & 29.8 & 60.4 & 58.1 & 49.5 & 46.2 & 49.0 & 41.0 & 45.3 & 33.8 & 36.2 \\
\hline India & 52.15 & 58.7 & 60.2 & 14.9 & 18.8 & 13.2 & 57.5 & 54.3 & 47.1 & 44.3 & 62.9 & 56.7 & 55.7 & 44.4 & 46.7 \\
\hline
\end{tabular}

Note: $\quad \mathrm{VA}=$ Voice and Accountability ; PS= Political Stability; GE= Government Effectiveness; RQ= Regulatory Quality; RL= Rule of Law; CC Control of Corruption, 07= 2007 and 09=2009 Source: World Development Indicators (2011)

In terms of overall ease of doing business, India ranked quite low at 134 compared to PRC's rank 79 respectively in 2001. Compared to PRC, India's performance was unsatisfactory in enforcing contracts, paying tax, closing business, registering property and trading across borders whereas PRC performed poorly in getting credit, and protecting investors (Table 35).

Table 35. Ease of Doing Business 2011 rankings for all economies are benchmarked to June 2010

\begin{tabular}{|l|l|l|l|l|l|l|l|l|l|l|}
\hline & $\begin{array}{l}\text { Ease of } \\
\text { Doing } \\
\text { Business }\end{array}$ & $\begin{array}{l}\text { Starting } \\
\text { Business }\end{array}$ & $\begin{array}{l}\text { Dealing } \\
\text { with } \\
\text { Construction } \\
\text { Permits }\end{array}$ & $\begin{array}{l}\text { Register } \\
\text { Property }\end{array}$ & $\begin{array}{l}\text { Getting } \\
\text { Credit }\end{array}$ & $\begin{array}{l}\text { Protect } \\
\text { Investors }\end{array}$ & $\begin{array}{l}\text { Pay } \\
\text { Tax }\end{array}$ & $\begin{array}{l}\text { Trade } \\
\text { Across } \\
\text { Border }\end{array}$ & $\begin{array}{l}\text { Enforce } \\
\text { Contract }\end{array}$ & $\begin{array}{l}\text { Close } \\
\text { Business }\end{array}$ \\
\hline U. K. & 4 & 17 & 16 & 22 & 2 & 10 & 16 & 15 & 23 & 7 \\
USA & 5 & 9 & 27 & 12 & 6 & 5 & 62 & 20 & 8 & 14 \\
Korea & 16 & 60 & 22 & 74 & 15 & 74 & 49 & 8 & 5 & 13 \\
Japan & 18 & 98 & 44 & 59 & 15 & 16 & 112 & 24 & 19 & 1 \\
South & 34 & 75 & 52 & 91 & 2 & 10 & 24 & 149 & 85 & 74 \\
Africa & 79 & 151 & 181 & 38 & 65 & 93 & 114 & 50 & 15 & 68 \\
Rusc & 123 & 108 & 182 & 51 & 89 & 93 & 105 & 162 & 18 & 103 \\
Brazil & 127 & 128 & 112 & 122 & 89 & 74 & 152 & 114 & 98 & 132 \\
India & 134 & 165 & 177 & 94 & 32 & 44 & 164 & 100 & 182 & 134 \\
\hline
\end{tabular}

Source: International Finance Corporation and World Bank (2010)

\subsection{Role of state and market}

During 1950s both India and the PRC followed inward-oriented, state-controlled economic strategies based on import protection and state-directed resource allocation polices for growth and development (Wignaraja, 2011). In pre-reform years, the PRC's economy was dominated by the public sector because they adopted the Soviet-style planned economy. India, in contrast, was a mixed economy where state-owned enterprises and private businesses thrived together (Bajpai and Jian 1996). In comparisons to PRC, the private sector played a stronger role in 
India. India has several private sector companies with strong international presence and world-wide recognition.

However, for both countries post-reform strategies, highlight the importance of using market extensively for their growth and development.

PRC government polices notably demographic policies and agricultural reforms in the 1980s, industrial and economic reforms of 1990 s and 2000, played important role in promoting investment driven, export led, market-oriented growth (Guruswamy, et.al., 2009). In particular, public-sector led industrial development policies and export-oriented strategies led to the expansion of the manufacturing sector and high economic growth. Meanwhile India adopted policies that stimulated consumer demand and promoted entrepreneurship. On the other hand the PRC's industrial policy was likened to the East Asian pattern of development. Basically, the PRC opened up its markets and implemented policy reforms in order to attract foreign direct investment. Along with government support, infrastructure and low wage-labor required by these investors were also available making it a preferred choice of investment destination (ibid).

Like PRC, India's growth was also supported by government-led economic and social reforms like agricultural reforms, abolition of centrally managed system of licenses and subsidies and opening up of the economy. However, industrialization was not so successful in India compared to PRC. In early years, the Indian government opted for an import-substitution regime with a closed economy (Staley 2006). This limited competition and bred inefficiency in the manufacturing sector. When the government opened up the economy, rigid labor laws, the presence of many labor parties, the lack of physical and social infrastructure also impeded growth in the manufacturing sector (Singh 2007).

\subsection{Trends in the Development of Entrepreneurs}

Entrepreneurship has been identified as one of the key drivers of economic development for India and China. According to studies carried out by the Global Entrepreneurship Monitor (GEM), China and India have registered high levels of entrepreneurship in their economies with a large young population; however the patterns of support and investment in the two countries are different. While there are differences in the government and political structure in both countries, China and India both have a large population, rich cultural heritage and a large natural resource base ( Goel et al. 2007).

In India, GEM surveys have found that that early-stage entrepreneurial activity is gender sensitive with more men engaging in entrepreneurship compared to women due to cultural, societal and economic reasons (Singer et. al, 2015). Further the three major constraints for entrepreneurship in India are the following: "government regulation and policies, entrepreneurial education at primary and secondary school level, and transfer and commercialization of R\&D - new know-how and technologies" (GEM, 2014).

The Global Entrepreneurship Summit held by Harvard Business School (2008), the contrasting cases of entrepreneurship in India and China was discussed in detail. Some of the key points from the discussion are the following:

1. In China, there are several factors that contribute to entrepreneurial activity such as China's large homogenous market to the country's physical infrastructure (highway system, high-speed rail system, new airports, and water-based transportation systems) which helps to support sales in the domestic market. Further Chinese entrepreneurs have significant funding available from sources such as banks and private equity, which is very active in China from venture capital perspectives.

2. However, some of the challenges for entrepreneurs in China is surviving a cut-throat and competitive business environment making it hard to start a venture. Further "soft" infrastructure such as differences in licensing system in different provinces, language barriers such as lack of English language skills in the domestic market makes it difficult 
for Chinese entrepreneurial ventures to globalize and become competitive in the international market.

3. For India, English language skills are not a barrier as there is a huge population with good English skills and workers available at low cost. However, high levels of poverty in the country. Unlike China, India has a heterogeneous market with 14 official languages along with diverse cultures and regions, making doing business in India and forging national policies a challenge. Further costs are slowly increasing in India, thus it is important for ventures to focus on talent and innovation to differentiate themselves.

4. Overall, new ventures in both countries provide employment opportunity for a large proportion of the population. As entrepreneurship grows in both countries, it is important that India and China strive to create global company cultures as global competitiveness and openness is the only way forward to be successful in the international business environment.

\section{Conclusion}

While many studies refer to the PRC and India as emerging economies, looking at a longer historical data, the term re-emerging is more appropriate. In recent decades, the PRC and India has experienced impressive growth and they are expected to lead the global economy in the years to come. This remarkable growth has not only reduced poverty and increased per capita income but it has also improved the overall human development in both countries. Moreover, both countries shifted out from centrally planned states to market-oriented economies, thus, attracting foreign capital, increasing productivity and expanding trade.

Analysis revealed that while both growing rapidly, the PRC and India took different growth paths and followed different growth models in different stages of development. On one hand, the PRC has emerged as a manufacturing powerhouse of the world and on the other hand, while India became a strong service sector center. The PRC's growth has been driven by net exports, manufacturing sector and investment while for India by consumption and services sector. Various policies starting from education policies which prioritized primary education in the PRC and higher education in India to infrastructure development policies which stimulated trade in goods in the PRC and the ICT sector in India helped to achieve this outcome.

While there are differences in the approaches that these countries took, a key similarity is that liberalization, deregulation and opening up of markets have contributed to the growth of their economies. Trade policies opened up their markets to trade, and hence greater local competition, increased market efficiency and competitiveness in both countries. Undertaking several bilateral FTAs facilitated them access to foreign markets which, in turn, allowed them to expand their exports. In addition, investment incentives which not only increased capital formation but also brought in technology to their countries.

The developing countries, especially emerging economies, that are also struggling to improve their economic development and quality of life amidst slowing economic growth in recent years.

\section{References}

Ahluwalia, Montek Singh (1994). India's Economic Reforms, based on the author's address inaugurating the Seminar on India's Economic Reforms at Merton College, Oxford, June 1993 updated to include developments up to March 1994.

Anukoonwattaka, Witada (2011). Comparative overview of economic profiles and roles of China and India in Asian international production networks", in Anukoonwattaka, W. and Mikic, M. (Eds), India: A New Player in Asian Production Networks? , Studies in Trade and Investment 75, United Nations Economic and Social Commission for Asia and the Pacific, Bangkok.

Asian Development Bank and ADB Institute (2014). ASEAN, PRC and India Great Transformation, ADB Institute, Tokyo. 
Asian Development Bank (ADB) (2011). Asia 2050: Realizing the Asian Century. Eds. Harinder S. Kohil, Ashok Sharma and Anil Sood, Sage Publications Pvt Ltd.

Asian Productivity Organization (APO) (2011). Asian Productivity Organization (APO) Database.

Available:http://www.apo-tokyo.org/00e-books/IS-45_DB2011/APO_2011e_edition.pdf

Athukorala, P. (2011), Asian trade flows: trends, patterns, and projections, ADB Economics Working Paper Series No 241, Asian Development Bank, Manila. Accessed 15 August, 2011.

Athukorala, Prema-chandra (2010). Production Networks and Trade Patterns in East Asia: Regionalization or Globalization? ADB Working Paper Series on Regional Economic Integration No. 56.

Bardhan, Pranab (2010). Awakening Giants, Feet of Clay: Assessing the Economic Rise of China and India. Princeton University Press.

Bhattacharyay, Biswanth (2006). Understanding the Latest Wave and Future of Regional Trade and Economic Cooperation Agreements in Asia, CESIfo Working Paper No. 1856, Center for Economic Studies and Ifo Institute for Economic Research, University of Munich. November.

Bhattacharya. Swapan and Bhattacharyay, Biswanth (2007). Gains and Losses of India-China Trade Cooperation - a Gravity Model Impact Analysis", CESifo Working Paper Series 1970, CESifo Group Munich, University of Munich, April.

Brajesh, Jha (2006). "Employment Wages and Productivity in Indian Agriculture" IEG Working Paper Series No. E/266/2006.

Brandt, Loren (2008). "China's Great Transformation", China's Great Transformation, Cambridge: Cambridge University Press.

Batra, Amitra and Zeba Khan (2005). Revealed Comparative Advantage: An Analysis for India and China. ICRIER Working Paper Series No. 12.

Chan, Kam-Wing (2008). 'Internal labour migration in China: trends, geographical distribution and policies', Proceedings of the United Nations Expert Group meeting on Population Distribution, Urbanisation, Internal Migration and Development, United Nations.

Available:http://www.un/pop/egm-urb/2008/05 Accessed 15 August, 2011.

Chaudhuri, Shubham and Martin Ravallion (2006). Partially Awakened Giants: Uneven Growth in China and India. World Bank Policy Research Working Paper 4069, November 2006. Available:http://www-wds.worldbank.org/servlet/WDSContentServer/WDSP/IB/2006/11/1 7/000016406_20061117113609/Rendered/PDF/wps4069.pdf Accessed 15 August, 2011.

CEPII. CHELEM 2011. Database, http://www.cepii.fr/anglaisgraph/bdd/chelem.htm

Chen, Shaohua and Ravallion Martin (2008). The Developing World is Poorer Than we Though, But No less Successful in the Fight against Poverty. Policy Research Working Paper, WPS4703, August 2008, the World Bank.

Available:http://siteresources.worldbank.org/JAPANINJAPANESEEXT/Resources/51549 7-1201490097949/080827_The_Developing_World_is_Poorer_than_we_Thought.pdf Accessed September 28, 2011.

Cho, Yoon Je (1999) "The Banking System of the People's Republic of China" in Asian Development Bank, Rising Challenges in Asia: A Study of Financial Markets -The People's Republic of China (Manila: Asian Development Bank, 1999), p. 62.

DeLong, J. Bradford (2001). "India Since Independence: An Analytic Growth Narrative," in Dani Rodrik, ed., Modern Economic Growth: Analytical Country Studies. Depository Services Program, 2008. India Agricultural Policy Review. Available: http://dsp-psd.pwgsc.gc.ca/collection_2009/agr/A38-3-5-1-1E.pdf, Accessed August 13th 2011.

Dobson, Wendy (2007) Financial reforms in China and India: A comparative analysis. Institute for International Business Working Paper Series No. 9.

The Heritage Foundation (2011). Economic Freedom Ranking the Countries. Available: http://www.heritage.org/index/ranking, Accessed August 15, 2011.

Fan, S., C. Chan-Kang, and A. Mukherjee (2005). "Rural and Urban dynamics and poverty: Evidence from China and India." Draft Paper, IFPRI, Washington, D.C. 
Farrell, Diana and Susan Lund (2006). A Tale of Two Financial Systems: A Comparison of India and China. McKinsey Global Institute. Available: http://www.mckinsey.com/mgi/reports/pdfs/indiachinafinsys/tale_of_two_financial_syste ms.pdf.

Felipe, Jesus, Kristine Kinantar and Joseph Lim (2006). Asia's Current Account Surplus: Savings Glut or Investment Drought? Asian Development Review, vol. 23, no. 1, pp.16-54.

Feng, Wang (2005). Can China Afford to Continue Its One-Child Policy? Analysis from the East West Center No. 77.

Gerhaeusser, Klaus; Iwasaki Yoshihiro; Tulasidhar, V.B. (2010). Resurging Asian Giants: Lessons from the People's Republic of China and India. Manila: Asian Development Bank.Available http://www.adb.org/documents/books/resurging-asian-giants/resurging-asian-giants.pdf Accessed 15 August 2011

Gill, Indermit and Homi Kharas (2007). An East Asian Renaissance: Ideas for Economic Growth. World Bank: The International Bank for Reconstruction and Development.

GOI (2011). Economic Outlook 2011/12, Government of India, Economic Advisory Council to the Prime Minister, New Delhi. Available: http://pmindia.nic.in/EAC-2011-12.pdf. Accessed September 28, 2011.

Goel, A., Vohra, N., Zhang, L., \& Arora, B. (2007). Attitudes of the youth towards entrepreneurs and entrepreneurship: A cross-cultural comparison of India and China. Journal of Asia Entrepreneurship and Sustainability, 3(1), 1-37.

Goldman, Charles A; Kumar Krishna B.; Liu Y. (2008). Education and the Asian Surge: A Comparison of the Education Systems in India and China. Center For Asia Pacific Policy. Available at http://www.rand.org/pubs/occasional_papers/2008/RAND_OP218.pdf Accessed 15 August, 2011

Gullapalli, Sailaja (2005). India and Globalization: Policy of Look East and Beyond. Research and Practice in Social Science, Vol.1 No.1, pp. 80-89.

Guruswamy, M.; Kau, A.; Handa, V. (2009). Can India Catch up with China? Economic and Political Weekly, Vol. 38, No. 45 (Nov. 8-14, 2003), pp. 4749-4751 Available http://cis.uchicago.edu/outreach/summerinstitute/2009/documents/cis sti2009-mehta-ca $\mathrm{n}$ india catch up with china.pdf Accessed September 15, 2011.

Harvard Global Business Summit (2008). Global Entrepreneurship: The Contrasting Case of China and India. Available at http://www.hbs.edu/centennial/businesssummit/global-business/global-entrepreneurshipthe-contrasting-cases-of-china-and-india.pdf accessed 13 February 2016.

Heritage Foundation (2011). The Index of Economic Freedom 2011, the Heritage Heritage Foundation and Wall Street Journal. Available: http://www.heritage.org/index/ranking Accessed 15 August 2011

International Finance Corporation and World Bank (2010). Doing Business 2011, Available at http://www.doingbusiness.org/ /media/GIAWB/Doing\%20Business/Documents/Annual-R eports/English/DB11-FullReport.pdf Acessed 15 August 2011.

Lee, Jong-Wha and Kiseok Hong (2010). Economic Growth in Asia: Determinants and Prospects. ADB Economics Working Paper Series No. 220. Available: http://www.adb.org/documents/working-papers/2010/economics-wp220.pdf

Leger, Lucas (No date). India vs. China: How far the political system could influence growth? Available in http://spontaneousorder.in/?p=1205 Accessed September 15, 2011.

$\mathrm{Li}$, Shantong and Xu Zhaoyuan (2008). The Trend of Regional Disparity in the People's Republic of China. ADB Institute Discussion Paper No. 85.

Kaminsky Graciela L.; Reinhart Carmen M. (1999). The Twin Crises: The Causes of Banking and Balance-Of-Payments Problems. The American Economic Review, Vol.89, No. 3(Jun. 1999), 473-500 Available http://www.macroeconomics.tu-berlin.de/fileadmin/fg124/financial_crises/literature/Kamin sky_Reinhart_1999_pdf¥ Accessed 15 August 2011.

Maddison, Angus (2001). The World Economy: A Millennial Perspective, Paris, OECD.

McKinsey Global Institute (2007). The 'Bird of Gold': The Rise of India's Consumer Market. Accessed 
http://www.mckinsey.com/mgi/reports/pdfs/india_consumer_market/MGI_india_consume r_chapter_1.pdf August 152011.

Mullen, Kathleen; Orden, David; and Gulati, Ashok (2005). Agricultural Policies in India: Producer Support Estimates 1985-2002. Markets, Trade and Institutions Division, International Food Policy Research Institute (IFPRI), MTID Discussion Paper No. 82. http://www.ifpri.org/sites/default/files/publications/mtidp82.pdf. Accessed on 15 August, 2011

NSS (2010). Migration in India, National Sample Survey Office, NSS Report No. 533, Ministry of Statistics and Programme Implementation, Government of India, June 2010.

NBS (2007). National Bureau of Statistics of China. Available http://www.stats.gov.cn/english/ Accessed 15 August 2011.

----- (2002). National Bureau of Statistics of China. Available http://www.stats.gov.cn/english/ Accessed 15 August 2011.

OECD (2005). Agricultural Policy Reform in China, Policy Brief, Organization for Economic Co-operation and Development. Accessed September 15, $2011 . \quad$ Available http://www.oecd.org/dataoecd/3/48/35543482.pdf

Ohta, Hideaki (2010). Effectiveness of Capital Controls in Asia: India and China as successful cases for capital account liberalization, Working Paper Series No. 17, Center for China and Asian Studies, Nihon University College of Economics, February. :

Panagaria, Arvind (2004). "Growth and Reforms During 1980s and 1990s." Economic and Political Weekly, June 19, pp. 2581-94.

Price Waterhouse Coopers (2010) in Singha, Prabhakar. India can become 3rd largest economy by 2012: PwC. The Times of India. January 24, 2010. Available: http://articles.timesofindia.indiatimes.com/2010-01-23/india-business/28141273_1_powe r-parity-largest-economy-global-economic-power

Prasad, Eswar (2009). Rebalancing Growth in Asia. IZA DP No. 4298.

Ravallion, Martin and Chen Shaohua (2007). China's (uneven) Progress Against Poverty. Journal of Development Economics, 82 (1): 1-42.

Rao, Nirmala; Kai-Ming Cheng; and Kirti Narain (2003). "Primary Schooling in China and India: Understanding How Socio-Contextual Factors Moderate the Role of the State," International Review of Education, Vol. 49,No. 1-2, 2003, pp. 153-176.

Rodrik, Dani (2002). "Institutions, Integration, and Geography: In Search of the Deep determinants of Economic Growth," in Dani Rodrik, ed., Modern Economic Growth: Analytical Country Studies

Roland, Christian (2006). Banking Sector Reforms in India and China-A Comparative Perspective.

http://unpan1.un.org/intradoc/groups/public/documents/apcity/unpan024226.pdf

Accessed August 15, 2011

Schiff and Valdez (1992). The Plundering of Agriculture in Developing Countries. Washington DC: International Bank for Reconstruction and Development.

Singer, S., Amoros J. E., and Moska, D. (2015), Global Entrepreneurship Monitor, 2104 Global Report,

http://www.babson.edu/Academics/centers/blank-center/global-research/gem/Document s/GEM\%202014\%20Global\%20Report.pdf

Singh, Nirvikar (2007). Fiscal Decentralization in China and India: Competative, Cooperative or Market Preserving Federalism? Available:

http://people.ucsc.edu/ boxjenk/wp/Fiscal Decentrl-China-India.pdf Accessed 13 August $\underline{2011}$

Staley, Sam (2006). The Rise and Fall of Indian Socialism: Why India Embraced Economic Reform. Reason Magazine. Accessed September 13, 2011. Available

http://reason.com/archives/2006/06/06/the-rise-and-fall-of-indian-so

Swamy, S.(2003) Economic Reforms and Performances: China and India in Comparative Perspective, Konark Publishing Ltd, New Delhi.

United Nations (2008). World Urbanization Prospects: The 2007 Revision, Department of Economic and Social Affairs (DESA), New York.

United Nations (2010). Human Development Indicators, 2010, United Nations, New York.

United Nations (2011). World Population Prospects: The 2010 Revision, United Nations, New 
York.

Wajwani, K.; Kanbur, R.; and Zhang, X. (2006). Comparing the Evalution of Spatial Inequality in China and India: A fifty-Year Perspective. Development Strategy and Governance Division, International Food Policy Research Institute, Discussion Paper No. 44. Available: http://ageconsearch.umn.edu/bitstream/55409/2/dsgdp44.pdf Accessed 12 August, 2011.

Wignaraja, Ganeshan (2011). Economic Reforms, Regionalism, and Exports: Comparing China and India, policy studies 60, East-West Center, Hawaii.

Wilson, Edgar, Jayanthakumaran, Kankesu; and Verma, Reetu. 2011. Demographics, Labor Mobility, and Productivity, background paper prepared for ADBI/ADB's study "ASEAN, China and India: 2030.

World Bank (2011). World Development Indicators 2011. Available: http://data.worldbank.org/data-catalog/world-development-indicators.

Zhuang, Juzhong. 2011. ASEAN, PRC, and India Growth Projections 2010-2030. Unpublished. Manila,: Asian Development Bank 